\title{
Structure and Thermodynamics of Uranium-Containing Iron Garnets
}

Xiaofeng Guo ${ }^{1,2}$, Alexandra Navrotsky ${ }^{2, *}$, Ravi K. Kukkadapu ${ }^{3}$, Mark H. Engelhard ${ }^{3}$, Antonio Lanzirotti4, Matthew Newville ${ }^{4}$, Eugene S. Ilton ${ }^{5}$, Stephen R. Sutton ${ }^{4,6}$, and Hongwu Xu ${ }^{1}$

${ }^{1}$ Earth and Environmental Sciences Division, Los Alamos National Laboratory, Los Alamos, NM 87545, USA

${ }^{2}$ Peter A. Rock Thermochemistry Laboratory and Nanomaterials in the Environment, Agriculture and Technology Organized Research Unit, University of California, Davis, CA 95616, USA

${ }^{3}$ Environmental Molecular Sciences Laboratory, Pacific Northwest National Laboratory, Richland, WA 99354, USA

${ }^{4}$ Center for Advanced Radiation Sources, University of Chicago, Chicago, Illinois 60637, USA

${ }^{5}$ Pacific Northwest National Laboratory, Richland, WA 99352, USA

${ }^{6}$ Department of Geophysical Sciences, University of Chicago, Chicago, Illinois 60637, USA

Keywords: uranium; garnet; X-ray absorption spectroscopy; X-ray photoelectron spectroscopy; calorimetry; structure. 
Abstract: Use of crystalline garnet as a waste form phase appears to be advantageous for accommodating actinides from nuclear waste. Previous studies show that large amounts of uranium (U) and its analogues such as cerium (Ce) and thorium (Th) can be incorporated into the garnet structure. In this study, we synthesized $\mathrm{U}$ loaded garnet phases, $\mathrm{Ca}_{3} \mathrm{U}_{x} \mathrm{Zr}_{2-x} \mathrm{Fe}_{3} \mathrm{O}_{12}(x=0.5-$ 0.7), along with the endmember phase, $\mathrm{Ca}_{3}\left(\mathrm{Zr}_{2}\right) \mathrm{SiFe}_{2}^{3+} \mathrm{O}_{12}$, for comparison. The oxidation states of $\mathrm{U}$ were determined by $\mathrm{X}$-ray photoelectron and absorption spectroscopies, revealing the presence of mixed pentavalent and hexavalent uranium in the phases with $x=0.6$ and 0.7 . The oxidation states and coordination environments of $\mathrm{Fe}$ were measured using transmission ${ }^{57} \mathrm{Fe}$ Mössbauer spectroscopy, which shows that all iron is tetrahedrally coordinated $\mathrm{Fe}^{3+}$. $\mathrm{U}$ substitution had a significant effect on local environments, the extent of $U$ substitution within this range had a minimal effect on the structure, and unlike in the $x=0$ sample, Fe exists in two different environments in the substituted garnets. The enthalpies of formation of garnet phases from constituent oxides and elements were first time determined by high temperature oxide melt solution calorimetry. The results indicate that these substituted garnets are thermodynamically stable under reducing conditions. Our structural and thermodynamic analysis further provides explanation for the formation of natural uranium garnet, elbrusite-(Zr), and supports the potential use of $\mathrm{Ca}_{3} \mathrm{U}_{x} \mathrm{Zr}_{2-x} \mathrm{Fe}_{3} \mathrm{O}_{12}$ as viable waste form phases for $\mathrm{U}$ and other actinides. 


\section{Introduction}

Safe disposal of highly radioactive waste from nuclear reactors or dismantled nuclear weapons is a daunting challenge due to potential deleterious environmental effects over thousands or even millions of years. Currently in the United States, France, United Kingdom, Belgium, Germany, Japan, and Russia, vitrification processes using borosilicate or aluminophosphate glassy matrices (Ewing, 1999, 2006; Grambow, 2006; Laverov et al., 2008; Lutze and Ewing, 1988; Weber et al., 2009) have been industrialized for immobilization of commercial nuclear waste. However, it remains unclear whether such glass-based systems are sufficiently stable for permanent encapsulation of long lived nuclides, such as the higher actinides. Since the 1970s, there have been numerous investigations of alternative waste forms. Considerable efforts have been focused on crystalline ceramics (Burakov et al., 1999; Ewing et al., 2004; Kesson and Ringwood, 1983; Lumpkin, 2006; Omel'yanenko et al., 2007; Ringwood, 1982; Rusakov et al., 2005; Sinclair and Ringwood, 1981; Urusov et al., 2005; Utsunomiya et al., 2005; Weber et al., 1997; Weber et al., 2009; Yudintsev et al., 2002; Yudintsev et al., 2007), which may serve as more durable and thus safer waste forms with high loadings of radionuclides. Various tailored ceramic forms containing mineral phases such as garnet, perovskite, monazite, pyrochlore, zircon, zirconolite, and defect fluorite, (Lumpkin, 2006; Navrotsky et al., 2013; Yudintsev et al., 2007) have been studied in terms of their chemical durability, waste loading, radiation tolerance and other related properties.

Garnet, a relatively new host for accommodation of actinides, was proposed in a number of recent studies (Burakov et al., 2000; Burakov and Strykanova, 1998; Galuskina et al., 2010; Guo et al., 2015a; Laverov et al., 2010; Laverov et al., 2003; Livshits, 2008; Rak et al., 2013b; Rusakov et al., 2005; Stefanovsky et al., 2010; Utsunomiya et al., 2002a; Utsunomiya et al., 2002b; Utsunomiya et al., 2005; Yudintsev et al., 2002; Yudintsev et al., 2007; Zamoryanskaya and Burakov, 2000; Zhang et al., 2010) due to its large loading of actinides and good chemical 
flexibility. The garnet structure has been shown to incorporate actinides in various oxidation states (Burakov et al., 2000; Burakov and Strykanova, 1998; Galuskina et al., 2010; Guo et al., 2014a; Laverov et al., 2010; Rak et al., 2013b; Rusakov et al., 2005; Stefanovsky et al., 2010; Yudintsev et al., 2002; Zamoryanskaya and Burakov, 2000). Notably, significant amounts of U were found in natural uranium bearing garnets, kimzeite (Galuskina et al., 2008) ( 22 wt.\% U) and elbrusite(Zr) (Galuskina et al., 2010) ( 27 wt. \% U), as well as in synthetic garnets ( 30 wt. \% U) (Burakov et al., 1999; Burakov and Strykanova, 1998; Laverov et al., 2010; Utsunomiya et al., 2002a; Youdintseva, 2005; Yudintsev et al., 2002; Zamoryanskaya and Burakov, 2000). The presence of U-containing natural garnets highlights their long-term stability as a mineral analogue for ceramic waste forms (Galuskina et al., 2010; Livshits, 2008; Lumpkin, 2006). Furthermore, the negligible influence of alpha decay damage on the leaching rate of garnets in aqueous solution (Livshits, 2008) suggests their robust chemical durability in nature; they can maintain their crystalline integrity when exposed to subsurface water. Garnet has been studied extensively for its response to alpha decay radiation damage (Laverov et al., 2003; Utsunomiya et al., 2002a; Utsunomiya et al., 2002b; Utsunomiya et al., 2005; Yudintsev et al., 2002; Zhang et al., 2010). Radiation tolerance measurements show that the average amorphization dose for garnet is comparable to that for zircon (Utsunomiya et al., 2002a; Utsunomiya et al., 2002b; Zhang et al., 2010), and the radiation response of garnet is topologically constrained, thus being less related to its actual chemical composition (Zhang et al., 2010). The implication is that garnets with different compositions may have similar high degrees of radiation tolerance. In addition, the chemical stability of garnets is not compromised significantly by amorphization (Laverov et al., 2010; Livshits, 2008), where partially amorphized garnets remain more resistant to leaching than other ceramic waste forms (Livshits, 2008; Lumpkin, 2006).

However, so far only ferric garnets have been found to incorporate significant amounts of actinides, including $\mathrm{U}, \mathrm{Np}, \mathrm{Pu}$, or $\mathrm{Ce}$ and Th as surrogates of higher actinides (Guo et al., 2015a; 
Laverov et al., 2010; Livshits, 2008; Stefanovsky et al., 2010; Urusov et al., 2004; Yudintsev et al., 2002). A garnet framework with large unit cell dimensions, forming from $\left[\mathrm{FeO}_{6}\right]$ octahedra and $\left[\mathrm{FeO}_{4}\right]$ tetrahedra, can accommodate large actinide ions. A positive correlation exists between the capacity of garnet to accommodate actinides and Fe content (Burakov et al., 1999; Laverov et al., 2010; Omel'yanenko et al., 2007; Youdintseva, 2005; Yudintsev et al., 2002). Recent density functional theory (DFT) calculations on incorporation of actinides ( $\mathrm{U}, \mathrm{Np}$, and $\mathrm{Pu}$ ) in $\mathrm{Ca}_{3}(\mathrm{Ti}, \mathrm{Zr}, \mathrm{Hf}, \mathrm{Sn})_{2}\left(\mathrm{Fe}_{2} \mathrm{Si}\right) \mathrm{O}_{12}$ confirmed the crucial role of $\mathrm{Fe} 3 d$ states in stabilizing actinides within the ferric garnet structure. Both neptunium and plutonium are important in spent nuclear fuel but they occur at much lower concentrations than uranium. $\mathrm{Np}$ - and Pu-containing garnet ceramics were previously reported in a ferric garnet system (Stefanovsky et al., 2010). Such systems were not studied in the present work.

Crystal chemical and energetic insights about ferric garnets have been obtained by studying the garnet phases with surrogates of higher actinides such as $\mathrm{Ce}$ and Th. Previous studies showed that $\mathrm{Y}_{3} \mathrm{Fe}_{5} \mathrm{O}_{12}$ (YIG) can incorporate high concentrations of Ce in its structure, (Gramsch and Morss, 1994; Guo et al., 2015a; Guo et al., 2014a; Kum et al., 2004; Laverov et al., 2010; Zamoryanskaya and Burakov, 2000) and the substituted Ce may be in different oxidation states (Guo et al., 2014a). Ce at high concentrations tends to be tetravalent, coupled with reduction of tetrahedral $\mathrm{Fe}^{3+}$ to $\mathrm{Fe}^{2+}$ in YIG (Guo et al., 2014a). Calorimetric analysis of $\mathrm{Ce}^{3+} \mathrm{Fe}^{3+}-\mathrm{Ce}^{4+} \mathrm{Fe}^{2+}$ coupled substitution in Ce:YIG revealed that the energetically unfavorable Fe reduction causes strain energy attenuation favoring Ce incorporation (Guo et al., 2014a). Similar behavior was observed in Th substituted YIG (Guo et al., 2014c). Hence, the presence of $\mathrm{Fe}^{3+}$ in garnets can facilitate incorporation of actinides via reduction of $\mathrm{Fe}^{3+}$ to $\mathrm{Fe}^{2+}$.

Despite the extensive studies described above, the mechanisms of $\mathrm{U}$ incorporation in $\mathrm{Fe}$ garnets remain largely unclear (Rak et al., 2011; Utsunomiya et al., 2002b; Yudintsev, 2003; Yudintsev et al., 2002). This is due to difficulties of determining the multiple oxidation states 
(tetravalent, pentavalent, and hexavalent) and associated coordinations and occupancies (dodecahedral and octahedral sites) of $U$ in the garnet structure. Crystal chemical arguments dictate that $\mathrm{U}^{4+}$ only fits dodecahedral sites, while $\mathrm{U}^{6+}$ occupies octahedral sites. The presence of $\mathrm{U}^{5+}$ in octahedral sites was suggested to occur by transferring its extra electron to neighboring tetrahedral $\mathrm{Fe}^{3+}$, based on first principles calculation (Rak et al., 2013a). Correspondingly, the octahedral site, even though smaller than the dodecahedral site, may be more flexible to incorporate $\mathrm{U}$ with higher oxidation states.

In this study, we synthesized several iron garnet phases incorporating octahedral $\mathrm{U}$, as revealed by X-ray photoelectron spectroscopy (XPS) and X-ray absorption near edge structure (XANES) measurements. Three garnet samples, $\mathrm{Ca}_{3}\left(\mathrm{U}_{x} \mathrm{Zr}_{2-x}\right) \mathrm{Fe}_{3} \mathrm{O}_{12}$ with $\mathrm{U}$ substitution content $x$ ranging from 0.5 to 0.7 , were investigated. These phases can be considered as derivatives of the endmember mineral kerimasit, $\mathrm{Ca}_{3}\left(\mathrm{Zr}_{2}\right) \mathrm{SiFe}^{3+}{ }_{2} \mathrm{O}_{12}(x=0)$. In the garnet structure (space group Ia3d, Figure 1) (Geller, 1967; Gibbs and Smith, 1965; Novak and Gibbs, 1971), there are three types of cation-oxygen polyhedra: $\left[\mathrm{CaO}_{20}\right]$ dodecahedra, $\left[\mathrm{ZrO}_{6}\right]$ octahedra, and $\left[\mathrm{FeO}_{4}\right]$ or $\left[\mathrm{SiO}_{4}\right]$ tetrahedra. In U-bearing garnets, $\mathrm{U}$ substitutes for a portion of octahedrally coordinated $\mathrm{Zr}^{4+}$, and all the tetrahedral $\mathrm{Si}^{4+}$ is replaced by Fe. Thus from $x=0$ to $x=0.5$, the substitution scheme is 0.5 ${ }^{\mathrm{VI}} \mathrm{Zr}^{4+}+{ }^{\mathrm{IV}} \mathrm{Si}^{4+}=0.5{ }^{\mathrm{VI}} \mathrm{U}^{6+}+{ }^{\mathrm{IV}} \mathrm{Fe}^{3+}$. However, for $x>0.5$, a portion of $\mathrm{U}$ is found to be pentavalent, and some $\mathrm{Fe}^{3+}$ might be reduced to $\mathrm{Fe}^{2+}$ to maintain charge neutrality. The substitution scheme can be represented by: ${ }^{\mathrm{VI}} \mathrm{Zr}^{4+}+y^{,}{ }^{\mathrm{IV}} \mathrm{U}^{6+}+z,{ }^{\mathrm{IV}} \mathrm{Fe}^{3+}={ }^{\mathrm{IV}} \mathrm{U}^{6+}+y^{,}{ }^{\mathrm{VI}} \mathrm{U}^{5+}+z^{\prime}$ ${ }^{\mathrm{IV}} \mathrm{Fe}^{2+}$, though here how much $\mathrm{U}^{5+}$ is generated and/or $\mathrm{Fe}^{2+}$ is converted during the substitution need to be studied.

The thermodynamic of uranium-containing iron garnet is not well investigated before, so in this study, calorimetric techniques were used to determine enthalpies of formation to evaluate the stability of these phases as hosts for $\mathrm{U}$, and its relations associated with the structural evolution. 


\section{Methods}

\subsection{Sample synthesis}

$\mathrm{Ca}_{3}\left(\mathrm{Zr}_{2}\right) \mathrm{SiFe}_{2} \mathrm{O}_{12}$ was synthesized using solid state sintering method. Stoichiometric powders of $\mathrm{CaCO}_{3}$ (Alfa Aesar, $99.95 \%$ ), $\mathrm{ZrO}_{2}$ (Aldrich, $99 \%$ ), $\mathrm{SiO}_{2}$ (Alfa Aesar, $99.99 \%$ ), and $\mathrm{Fe}_{2} \mathrm{O}_{3}$ (Sigma-Aldrich, $99.99 \%$ ) were mixed and ground in an agate mortar with anhydrous alcohol as the grinding media for $1 \mathrm{~h}$. The obtained powder mixture was then pelletized and calcinated in air at $1250{ }^{\circ} \mathrm{C}$ for $24 \mathrm{~h}$.

Syntheses of $\mathrm{Ca}_{3}\left(\mathrm{U}_{x} \mathrm{Zr}_{2-x}\right) \mathrm{Fe}_{3} \mathrm{O}_{12}$ were conducted following a citrate-nitrate combustion route (Guo et al., 2005; Vajargah et al., 2007; Vaqueiro et al., 1996). Stoichiometric mixture of $\mathrm{Ca}\left(\mathrm{NO}_{3}\right)_{3} \cdot 4 \mathrm{H}_{2} \mathrm{O}$ (Fisher, $99 \%$ ), $\mathrm{ZrO}\left(\mathrm{NO}_{3}\right)_{2} \cdot y \mathrm{H} 2 \mathrm{O}$ (Alfa Aesar, $99.9 \%$ ), $\mathrm{UO}_{2}\left(\mathrm{NO}_{3}\right)_{2} \cdot 6 \mathrm{H}_{2} \mathrm{O}(\mathrm{SPI}-$ Chem, $99 \%$ ), and $\mathrm{Fe}\left(\mathrm{NO}_{3}\right)_{3} \cdot 9 \mathrm{H}_{2} \mathrm{O}$ (Sigma-Aldrich, $99.99 \%$ ) was dissolved in an aqueous solution of citric acid monohydrate (Alfa Aesar, 99.9\%), where the ratio of citric acid to nitrate was kept near 0.75 (Guo et al., 2005). The obtained solution was heated at $\sim 90{ }^{\circ} \mathrm{C}$ under constantly stirring by a magnetic bar to ensure homogeneity. Viscous gels formed, and were then heated at $350{ }^{\circ} \mathrm{C}$ for $\sim 2 \mathrm{~h}$. The dried powders went through self-propagating combustion (Vajargah et al., 2007) to form aggregates of loose powders that subsequently were pelletized for calcination in air at $1250{ }^{\circ} \mathrm{C}$ for $24 \mathrm{~h}$.

\subsection{Chemical and structural analyses}

XRD patterns of garnet samples were acquired using a Bruker D8 $\left(\mathrm{Cu} \mathrm{K} \mathrm{K}_{\alpha}\right.$ radiation, $40 \mathrm{kV}$, $30 \mathrm{~mA}$ ) from $15^{\circ}$ to $83^{\circ} 2 \theta$ with a step size of $0.011^{\circ}$ and a collection time of 2 s per step. Lattice parameters and $\mathrm{U} / \mathrm{Zr}$ site occupancies were determined using the Rietveld method (Rietveld, 1969) with the FullProf program (version 5.40, 2014). Chemical compositions and homogeneity of the samples were characterized by EPMA using a Cameca SX-100 electron microprobe coupled 
with WDS (15 kV accelerating voltage, $10 \mathrm{nA}$ beam current and a spot size of $1 \mu \mathrm{m})$. The synthesized powder samples were pelletized, sintered and polished prior to EPMA analysis. $\mathrm{Ca}_{2} \mathrm{SiO}_{4}, \mathrm{ZrO}_{2}, \mathrm{UO}_{2}, \mathrm{SiO}_{2}$ and $\mathrm{Fe}_{2} \mathrm{O}_{3}$ were used as analytical standards for $\mathrm{Ca}, \mathrm{Zr}, \mathrm{U}, \mathrm{Si}$ and $\mathrm{Fe}$, respectively. At least ten measurements were done for each sample.

XPS measurements on $\mathrm{Ca}_{3}\left(\mathrm{U}_{x} \mathrm{Zr}_{2-x}\right) \mathrm{Fe}_{3} \mathrm{O}_{12}$ samples were performed using a Kratos Axis DLD spectrometer equipped with a monochromatic X-ray source of $\mathrm{Al} \mathrm{K}_{\alpha}$ radiation $(1486.7 \mathrm{eV}$, $15 \mathrm{~mA}, 14 \mathrm{kV})$. The instrument work function was calibrated to give a binding energy (BE) of $83.96 \pm 0.05 \mathrm{eV}$ for the $\mathrm{Au} 4 \mathrm{f}_{7 / 2}$ line of metallic gold, and the spectrometer dispersion was adjusted to give a $\mathrm{BE}$ of $932.62 \pm 0.05 \mathrm{eV}$ for the $\mathrm{Cu} 2 \mathrm{p}_{3 / 2}$ line of metallic copper. High resolution measurements were carried out with an analysis area of $300 \times 700 \mu \mathrm{m}$ and a pass energy of $80 \mathrm{eV}$. The Kratos charge neutralizer system was used on all specimens. XPS spectra were chargecorrected to the main line of the carbon 1s spectrum (adventitious carbon) at $285.0 \mathrm{eV}$ and were analyzed using the CasaXPS software (version 2.3.16 PR 1.6).

To evaluate the oxidation state of U, XANES spectroscopy was performed at the GSECARS X-ray microprobe beamline (13-ID-E) at the Advanced Photon Source (APS), Argonne National Laboratory (Argonne, IL, USA). XANES spectra were collected in transmission mode using a $200 \mathrm{~mm}$ long, helium filled ion chamber to monitor incident flux, $\mathrm{I}_{0}$ (ADC IC-400-200) and a $50 \mathrm{~mm}$ long nitrogen filled ion chamber downstream of the sample to monitor transmitted flux, $\mathrm{I}_{1}$ (ADC 500-50). XANES spectra were obtained by scanning a $\mathrm{Si}(111)$ monochromator through the $\mathrm{U} \mathrm{L}_{\mathrm{III}}$ absorption edge $(\sim 17166 \mathrm{eV})$ and recording the total absorption. In the XANES region, the energy step sizes were $2.5 \mathrm{eV}$ from 17066 to $17146 \mathrm{eV}$ and $0.25 \mathrm{eV}$ from 17146 to $17191 \mathrm{eV}$. The $\mathrm{E}_{0}$ energy of the garnet XANES spectra was determined from the maximum of the first derivative of the absorption edge. The EXAFS portion of the spectra was then collected to a distance of $15 \AA^{-1}$. Dwell time at each energy step was $1 \mathrm{~s}$, and up to eight spectra were collected and summed to improve the signal-to-noise ratio. Energy 
calibration was obtained using a Y metal foil (first derivative peak defined to be $17037 \mathrm{eV}$ ). Two synthetic valence standards (Guo et al., 2016) were measured: $\mathrm{CrUO}_{4}$ and $\mathrm{MgUO}_{4}$. The samples and standards were prepared as thin powder layers each mounted between two Scotch tapes. The obtained XAS data were processed using the ATHENA and ARTEMIS software package(Ravel and Newville, 2005). For EXAFS fitting (shell by shell fitting, although only the first shell results are discussed here), $\chi(\mathrm{k})$ is weighted by $\mathrm{k} 2$. The calculated best fit bond distances ( $\mathrm{R}$ in $\AA$ ), coordination numbers $(N)$ and disorder factors (Debye-Waller $\left(\sigma^{2}\right.$ in $\left.\AA^{2}\right)$ for the first shell fits are presented in the Results and Discussion section.

${ }^{57} \mathrm{Fe}-$ Mössbauer spectra were collected using a $50-\mathrm{mCi}$ (initial strength) ${ }^{57} \mathrm{Co} / \mathrm{Rh}$ source. The velocity transducer MVT-1000 (WissEL) was operated in a constant acceleration mode (23 $\mathrm{Hz}, \pm 5$ or $12 \mathrm{~mm} / \mathrm{s})$. An Ar- $\mathrm{Kr}$ proportional counter was used to detect the radiation transmitted through the holder, and the counts were stored in a multichannel scalar (MCS) as a function of energy (transducer velocity) using a 1024 channel analyzer. Data were folded to 512 channels to give a flat background and a zero-velocity position corresponding to the center shift of a metal iron foil. Calibration spectra were obtained with a $25-\mu \mathrm{m}$-thick $\alpha-\mathrm{Fe}(\mathrm{m})$ foil (Amersham, England) placed in the same position as the sample to minimize errors due to geometry changes. A closedcycle cryostat (ARS, Allentown, PA) was employed for measurements below room temperature. Samples were prepared using a procedure similar to that described previously.(Peretyazhko et al., 2012)

\subsection{Calorimetry}

A custom built Tian-Calvet twin microcalorimeter (Navrotsky, 1977, 1997) operated at $802{ }^{\circ} \mathrm{C}$ was used for measurements of enthalpies of drop solution $\left(\Delta H_{\mathrm{ds}}\right)$ in molten lead borate $\left(2 \mathrm{PbO} \cdot \mathrm{B}_{2} \mathrm{O}_{3}\right)$ solvent. Oxygen gas was flushed inside the chamber of the calorimeter at $\sim 50$ $\mathrm{ml} / \mathrm{min}$ to maintain the head space gas above the solvent a constant composition, and bubbled 
through the melt at $\sim 5 \mathrm{~mL} / \mathrm{min}$ to maintain oxidizing conditions and facilitate dissolution of the sample and prevent local saturation. (Navrotsky et al., 1994) The calorimeter was calibrated using the heat content of $\alpha-\mathrm{Al}_{2} \mathrm{O}_{3}$ from transposed temperature drops of $\sim 5 \mathrm{mg} \alpha-\mathrm{Al}_{2} \mathrm{O}_{3}$ pellets. In each experiment, $\sim 5 \mathrm{mg}$ pelletized garnet sample was weighed on a microbalance and multiple drops were made to optimize the accuracy of the measurement. Uncertainties are reported as two standard deviations of the mean. The equipment, calibration and experimental method were described in detail elsewhere (Navrotsky, 1977, 1997, 2014).

\section{Results}

\subsection{Composition and structure}

The chemical compositions of the synthesized garnet samples, determined by electron probe microanalysis (EPMA) using wavelength dispersive spectroscopy (WDS), are as follows (Table $\mathrm{S} 1$ in the supplementary information, $\mathrm{SI}$ ): $x=0, \mathrm{Ca}_{3.0} \mathrm{Zr}_{2.0} \mathrm{Fe}_{2.1} \mathrm{Si}_{0.9} \mathrm{O}_{12} ; x=0.5$, $\mathrm{Ca}_{3.0}\left(\mathrm{U}_{0.5} \mathrm{Zr}_{1.5}\right) \mathrm{Fe}_{3.0} \mathrm{O}_{12} ; x=0.6, \mathrm{Ca}_{3.0}\left(\mathrm{U}_{0.6} \mathrm{Zr}_{1.4}\right) \mathrm{Fe}_{3.0} \mathrm{O}_{12} ;$ and $x=0.7, \mathrm{Ca}_{3.0}\left(\mathrm{U}_{0.7} \mathrm{Zr}_{1.3}\right) \mathrm{Fe}_{3.0} \mathrm{O}_{12}$. Previous study showed that synthesis of the samples with $x>0.7$ resulted in formation of $\mathrm{CaU}_{2} \mathrm{O}_{7}$ as a secondary phase (Cordfunke and Loopstra, 1967).

Powder X-ray diffraction (XRD) patterns of all the synthesized phases are indicative of a garnet structure (Figure 2). Clear differences are seen in peak intensities between $\mathrm{Ca}_{3}\left(\mathrm{Zr}_{2}\right) \mathrm{SiFe}_{2} \mathrm{O}_{12}$ and $\mathrm{Ca}_{3}\left(\mathrm{U}_{x} \mathrm{Zr}_{2-x}\right) \mathrm{Fe}_{3} \mathrm{O}_{12}$ due to the partial replacement of $\mathrm{Zr}$ by $\mathrm{U}$ coupled with the substitution of Si by Fe. Shifts of peaks to lower angles with increasing U content suggest lattice expansion. Rietveld analyses of the XRD data based on the structure model of Zaitsev et al. (Zaitsev et al., 2010) yielded good agreement between the measured and calculated patterns (see Table $\mathrm{S} 2$ in SI for details of the refinements). The refined lattice parameter of $\mathrm{Ca}_{3}\left(\mathrm{Zr}_{2}\right) \mathrm{SiFe}_{2} \mathrm{O}_{12}$ is 12.6182(1) $\AA$, and those of $\mathrm{Ca}_{3}\left(\mathrm{U}_{x} \mathrm{Zr}_{2-x}\right) \mathrm{Fe}_{3} \mathrm{O}_{12}$ with $x=0.5,0.6$, and 0.7, are 12.7908(2), 12.8017(2) and 12.8084(3) A, respectively. As shown in Figure 3, the unit-cell parameter of 
$\mathrm{Ca}_{3}\left(\mathrm{Zr}_{2}\right) \mathrm{SiFe}_{2} \mathrm{O}_{12}$ is much smaller than extrapolated from the linear fitting of the lattice parameters of $\mathrm{Ca}_{3}\left(\mathrm{U}_{x} \mathrm{Zr}_{2-x}\right) \mathrm{Fe}_{3} \mathrm{O}_{12}$ with $x=0.5,0.6$, and 0.7. This is primarily due to the substitution of small tetrahedrally coordinated $\mathrm{Si}^{4+}(0.26 \AA)$ by the much larger $\mathrm{Fe}^{3+}(0.49 \AA)$ in $\mathrm{Ca}_{3}\left(\mathrm{U}_{x} \mathrm{Zr}_{2-x}\right) \mathrm{Fe}_{3} \mathrm{O}_{12}$. Though a complex substitution scheme from $\mathrm{x}=0.5$ to 0.7 may be expected that the larger $\mathrm{U}^{5+}$ $(0.76 \AA)$ replaces portions of $\mathrm{Zr}^{4+}(0.72 \AA)$ in the octahedral sites (also maybe $\mathrm{Fe}^{2+}(0.76 \AA)$ replaces $\mathrm{Fe}^{3+}(0.63 \AA)$ in the tetrahedral sites), an almost lattice expansion of $\mathrm{Ca}_{3}\left(\mathrm{U}_{x} \mathrm{Zr}_{2-x}\right) \mathrm{Fe}_{3} \mathrm{O}_{12}$ towards higher U content was observed (Figure 3).

\section{2 $\mathrm{U}$ and Fe oxidation states}

XPS spectra of the $\mathrm{Ca}_{3}\left(\mathrm{U}_{x} \mathrm{Zr}_{2-x}\right) \mathrm{Fe}_{3} \mathrm{O}_{12}$ samples are shown in Figure 4. In each spectrum, there is a major $\mathrm{U}_{4} \mathrm{f}_{7 / 2}$ peak located at $381.4 \mathrm{eV}$, which corresponds to the binding energy (BE) of $\mathrm{U}^{6+}$. However, all the $\mathrm{U}_{4} \mathrm{f}_{7 / 2}$ peaks display distinct shoulders in the energy range of $380.1-380.2$ $\mathrm{eV}$, which suggest the presence of reduced uranium $\left(\mathrm{U}^{4+}\right.$ and/or $\left.\mathrm{U}^{5+}\right)$. Furthermore, the intensities of the shoulder peaks increase with increasing $U$ concentration from $x=0.5$ to 0.6 and 0.7 (Figure 4), indicating higher $\mathrm{U}^{4+} / \mathrm{U}^{5+}$ contents in the latter. While some $\mathrm{U}^{6+}$ may be reduced to $\mathrm{U}^{4+} / \mathrm{U}^{5+}$ during extended XPS measurements due to X-ray beam induced reduction (see Table S3 in SI for details), the fact that the $x=0.6$ and 0.7 samples have much higher $\mathrm{U}^{4+} / \mathrm{U}^{5+}$ contents implies that their reduced $U$ cations are at least partially from the originally synthesized samples. The concentrations of $U$ estimated from XPS data are in general agreement with those determined by EPMA. However, attempts to determine whether the reduced $U$ is $U^{4+}$ or $U^{5+}$ or both via fitting the $\mathrm{U}_{4} \mathrm{f}_{7 / 2}$ profiles did not reach a definite conclusion due to limited resolution of the data. Nevertheless, crystal chemical arguments suggest that the occurrence of $\mathrm{U}^{4+}$ is unlikely, as it would be too large $(0.89 \AA)$ to fit into the octahedral $\mathrm{Zr}$ sites $(0.72 \AA)$. On the other hand, the ionic radius of $\mathrm{U}^{5+}(0.76 \AA)$ is similar to that of $\mathrm{Zr}^{4+}$, and thus $\mathrm{U}^{5+}$ is probably the reduced uranium species in $\mathrm{Ca}_{3}\left(\mathrm{U}_{x} \mathrm{Zr}_{2-x}\right) \mathrm{Fe}_{3} \mathrm{O}_{12}$ garnets. Hence, the $\mathrm{U}^{5+} / \mathrm{U}$ ratios in samples with $x=0.6$ and 0.7 are 
determined to be 0.185 and 0.190 , respectively, and the corresponding formulas are $\mathrm{Ca}_{3}\left(\mathrm{U}^{6+}{ }_{0.49} \mathrm{U}^{5+}{ }_{0.11} \mathrm{Zr}_{1.40}\right)^{\mathrm{VI}}\left(\mathrm{Fe}^{3+}{ }_{2.91} \mathrm{Fe}^{2+}{ }_{0.09}\right)^{\mathrm{IV}} \mathrm{O}_{12}$ and $\mathrm{Ca}_{3}\left(\mathrm{U}^{6+}{ }_{0.57} \mathrm{U}^{5+}{ }_{0.13} \mathrm{Zr}_{1.30}\right)^{\mathrm{VI}}\left(\mathrm{Fe}^{3+}{ }_{2.73} \mathrm{Fe}^{2+}{ }_{0.27}\right)^{\mathrm{IV}} \mathrm{O}_{12}$. Noted here the formula were derived from semi-qualitative analysis, so that whether $\mathrm{Fe}^{2+}$ is presented in garnet needs to be checked by Mössbauer spectroscopy.

Since XPS is a surface sensitive technique (it typically probes the top $\sim 10 \mathrm{~nm}$ of a solid sample), we conducted synchrotron X-ray absorption spectroscopy (XAS) to characterize the U local structures in $\mathrm{Ca}_{3}\left(\mathrm{U}_{x} \mathrm{Zr}_{2-x}\right) \mathrm{Fe}_{3} \mathrm{O}_{12}$. Figure 5 shows $\mathrm{U}_{\mathrm{III}} \mathrm{XANES}$ spectra of the samples with $x=0.5,0.6$ and 0.7 , which give normalized absorption edge energies $\left(\mathrm{E}_{0}\right)$ of $17170.5,17170.3$ and $17170.3 \mathrm{eV}$, respectively. Although the differences are small, the decrease in $\mathrm{E}_{0}$ from $17170.5 \mathrm{eV}$ for $x=0.5$ to $17170.3 \mathrm{eV}$ for $x=0.6$ and 0.7 is consistent with the trend that $\mathrm{E}_{0}$ generally becomes smaller when $\mathrm{U}$ is reduced from $\mathrm{U}^{6+}$ to $\mathrm{U}^{5+}$ (Guo et al., 2016). The XANES edge energy decrease is in line with the correlation between the decreased formal charge and a lower core electron binding energy. (Soldatov et al., 2007) Moreover, extended X-ray absorption fine structure (EXAFS) fitting of the spectra yielded the radial distances of the first coordination shell from the central $\mathrm{U}$ of $2.07 \pm 0.01 \AA\left(\mathrm{N}=5.8 \pm 0.2, \sigma^{2}=0.0037 \pm 0.0005\right)$ for $x=0.5,2.10 \pm 0.02 \AA(\mathrm{N}=$ $\left.5.8 \pm 0.3, \sigma^{2}=0.0070 \pm 0.0008\right)$ for $x=0.6$ and $R=2.10 \pm 0.02 \AA\left(\mathrm{N}=5.9 \pm .3, \sigma^{2}=0.0072 \pm\right.$ 0.0008 ) for $x=0.7$. The lengthening of the $\mathrm{U}-\mathrm{O}$ bond when $x$ increases from 0.5 to 0.6 and 0.7 is in agreement with partial reduction of $\mathrm{U}^{6+}$ to the larger $\mathrm{U}^{5+}$, as also revealed by XPS.

To characterize the chemical and structural environments of $\mathrm{Fe}$, transmission ${ }^{57} \mathrm{Fe}$ Mössbauer spectroscopy (Guo et al., 2015a; Guo et al., 2014a) was carried out on the four garnet samples, at room temperature (RT), Figure 6. A major difference between the spectra of $x=0$ and U-substituted samples $(x=0.5,0.6$. and 0.7$)$ is the presence of an additional doublet (T1 in Figs. 6c and 6d) in the substituted garnets with significantly larger quadrupole splitting (QS) than that of the T2 doublet in the $x=0$ phase (Table S4 in SI). Unlike QS, the center shift (CS) values (Table S4) of T1 and T2 doublets in all the samples are similar (Fig. 6a) and are characteristic of 
$\mathrm{Fe}^{3+}$ in tetrahedral environments (Rettenwander et al., 2015; Urusov et al., 2004). These patterns are similar to RT Mössbauer spectra of $\left(\mathrm{Ca}_{2.5} \mathrm{Ce}_{0.5} / \mathrm{Th}_{0.5}\right) \mathrm{Zr}_{2} \mathrm{Fe}_{3} \mathrm{O}_{12}$ ferric garnets. ${ }^{37}$ The outer doublet spectral area of our $\mathrm{Ca}_{3}\left(\mathrm{U}_{x} \mathrm{Zr}_{2-x}\right) \mathrm{Fe}_{3} \mathrm{O}_{12}$ (71 - 75\%) samples, however, is significantly larger than that of $\left(\mathrm{Ca}_{2.5} \mathrm{Ce}_{0.5} / \mathrm{Th}_{0.5}\right) \mathrm{Zr}_{2} \mathrm{Fe}_{3} \mathrm{O}_{12}(30-40 \%)$ ferric garnets. These differences suggest that the tetrahedral sub-lattice in $\mathrm{Ca}_{3}\left(\mathrm{U}_{x} \mathrm{Zr}_{2-x}\right) \mathrm{Fe}_{3} \mathrm{O}_{12}$ is relatively more affected than that in $\mathrm{Ca}, \mathrm{Ce} / \mathrm{Th}, \mathrm{Zr}$-ferrites, which could be due to metal (and different types of metal) substitution in different sites - U over $16 a$ octahedral sites in the former as opposed to $\mathrm{Ce} / \mathrm{Th}$ in $24 c$ dodecahedral sites in the later. Furthermore: $i$ ) the similarities in the QS (and CS) values of the inner doublets of U-substituted garnets to the unsubstituted garnet $(x=0)$ suggests that the immediate environment of a fraction of the tetrahedral Fe sites are largely unaffected by $\mathrm{U}$ substitution, and ii) minor differences in outer/inner doublet ratios and Mössbauer spectral parameters of $x=0.5,0.6$, and 0.7 samples suggest that the extent of $U$ substitution in this range had a minimum effect on lattice distortions. Finally, based on the sole occurrence of tetrahedral $\mathrm{Fe}^{3+}$ (no octahedral $\mathrm{Fe}^{3+}$ and $\mathrm{Fe}^{2+}$ ), accounting for extra-frame work Fe impurity in $x=0.5$ sample, assuming non-precipitation of amorphous Fe-free solids, and mass balancing the octahedral charge with either $\mathrm{U}^{6+}$ or mix of $\mathrm{U}^{6+}$ and $\mathrm{U}^{5+}$, the bulk chemical formulae of $\mathrm{U}$-substituted phases are determined as: $x=0.5$, $\left.\mathrm{Ca}_{3}\left(\mathrm{U}^{6+}{ }_{0.5} \mathrm{Zr}_{1.5}\right)^{\mathrm{VI}}\left(\mathrm{Fe}^{3+}{ }_{3}\right)^{\mathrm{IV}} \mathrm{O}_{12} ; \quad x=0.6, \mathrm{Ca}_{3}\left(\mathrm{U}^{6+}{ }_{0.4} \mathrm{U}^{5+}{ }_{0.2} \mathrm{Zr}_{1.4}\right)^{\mathrm{VI}}\left(\mathrm{Fe}^{3+}{ }_{3}\right)^{\mathrm{IV}} \mathrm{O}_{12}\right) ; \quad$ and $\quad x=0.7$, $\mathrm{Ca}_{3}\left(\mathrm{U}^{6+}{ }_{0.3} \mathrm{U}^{5+}{ }_{0.4} \mathrm{Zr}_{1.3}\right)^{\mathrm{VI}}\left(\mathrm{Fe}^{3+}{ }_{3}\right)^{\mathrm{IV}} \mathrm{O}_{12}$. The derived chemical formulae concur well with EPMA results, yet the $\mathrm{U}^{5+}$ amount (from charge balance) is larger than the estimation from XPS or XANES. The above formulae are used for thermochemical analysis. Note, T1 and T2 sites are not shown in the above formulae.

\subsection{Thermochemical measurements}

Although $3 \mathrm{Na}_{2} \mathrm{O} \cdot 4 \mathrm{MoO}_{3}$ solvent can readily dissolve $\mathrm{U}$ bearing samples, and uranium has a well defined hexavalent state when dissolved in the melt (Guo et al., 2015b; Guo et al., 2014b; 
Helean et al., 2002), it was difficult to achieve high-accuracy calorimetric measurements on $\mathrm{Ca}_{3}\left(\mathrm{U}_{x} \mathrm{Zr}_{2-x}\right) \mathrm{Fe}_{3} \mathrm{O}_{12}$ samples because of the very small heat effects generated. The near-zero enthalpy of drop solution implies that the endothermic gain needed to heat the sample from room temperature to the calorimeter temperature is almost cancelled by the exothermic loss due to the sample dissolution; this makes the measurements susceptible to baseline variations. Thus in this work, lead borate (2PbO $\left.\cdot \mathrm{B}_{2} \mathrm{O}_{3}\right)$ solvent (Guo et al., 2015b) was chosen to dissolve garnet samples. Complete dissolution of U-bearing garnet samples was confirmed by furnace tests prior to calorimetric measurements, and the obtained $\Delta H_{\mathrm{ds}}$ values were indeed larger, allowing for more accurate determination (see Table 1). In this melt too the dissolved uranium is hexavalent.

$\Delta H_{\mathrm{ds}}$ values of garnet samples and auxiliary materials were used in thermochemical cycles in Table 2 to derive the enthalpies of formation $\left(\Delta H_{\mathrm{f}, \mathrm{ox}}\right.$, Table 1) of $\mathrm{Ca}_{3}\left(\mathrm{U}_{x} \mathrm{Zr}_{2-x}\right) \mathrm{Fe}_{3} \mathrm{O}_{12}$ from stable binary oxides $\left(\mathrm{CaO}, \mathrm{ZrO}_{2}, \mathrm{UO}_{3}, \mathrm{Fe}_{2} \mathrm{O}_{3}\right.$, and $\left.\mathrm{O}_{2}\right)$ at standard conditions. The obtained $\Delta H_{\mathrm{f}, \mathrm{ox}}$ values are $-55.1 \pm 8.0,-67.9 \pm 7.9$, and $-91.5 \pm 8.0 \mathrm{~kJ} / \mathrm{mol}$, for the phases with $x=0.5,0.6$, and 0.7 , respectively. In addition, standard enthalpies of formation $\left(\Delta H_{\mathrm{f}}^{\circ}\right)$ of $\mathrm{Ca}_{3}\left(\mathrm{Zr}_{2}\right) \mathrm{SiFe}_{2} \mathrm{O}_{12}$ and $\mathrm{Ca}_{3}\left(\mathrm{U}_{x} \mathrm{Zr}_{2-x}\right) \mathrm{Fe}_{3} \mathrm{O}_{12}$ from constituent elements were calculated based on thermochemical cycles in Table S5 in SI.

\section{Discussion}

\subsection{Thermodynamic stability of $\mathrm{Ca}_{3}\left(\mathrm{U}_{x} \mathrm{Zr}_{2-x}\right) \mathrm{Fe}_{3} \mathrm{O}_{12}$ garnets near ambient temperature}

To determine stability relations of $\mathrm{U}$-substituted garnet phases, their $\Delta H_{\mathrm{f}, \mathrm{ox}}$ values need to be compared with that of the prototype garnet, $\mathrm{Ca}_{3}\left(\mathrm{Zr}_{2}\right) \mathrm{SiFe}_{2} \mathrm{O}_{12}$, despite the fact that the $\Delta H_{\mathrm{f}, \mathrm{ox}}$ values of all these phases are exothermic. Thus the following substitution reaction is considered: 
$\mathrm{Ca}_{3} \mathrm{Zr}_{2} \mathrm{SiFe}_{2} \mathrm{O}_{12\left(\mathrm{~s}, 25^{\circ} \mathrm{C}\right)}+x \quad \gamma-\mathrm{UO}_{3\left(\mathrm{~s}, 25^{\circ} \mathrm{C}\right)}+1 / 2 \mathrm{Fe}_{2} \mathrm{O}_{3\left(\mathrm{~s}, 25^{\circ} \mathrm{C}\right)} \rightarrow \mathrm{Ca}_{3}\left(\mathrm{U}_{x} \mathrm{Zr}_{2-x}\right) \mathrm{Fe}_{3} \mathrm{O}_{12\left(\mathrm{~s}, 25^{\circ} \mathrm{C}\right)}+x$ $\mathrm{ZrO}_{2\left(\mathrm{~s}, 25^{\circ} \mathrm{C}\right)}+\mathrm{SiO}_{2\left(\mathrm{~s}, 25^{\circ} \mathrm{C}\right)}+(2 x-1) / 4 \mathrm{O}_{2\left(\mathrm{~g}, 25^{\circ} \mathrm{C}\right)}$

As shown in Table 3, the enthalpies of this reaction $\left(\Delta H_{\text {sub }}\right)$ are all positive. Although the entropy change is also positive due to emission of $\mathrm{O}_{2}$ gas (which increases the entropy by $205.15 \mathrm{~J} / \mathrm{mol} \cdot \mathrm{K}$ per mole of $\mathrm{O}_{2}$ released) (Chase, 1998) and U/Zr cation mixing (which increases the entropy on the order of $10 \mathrm{~J} / \mathrm{mol} \cdot \mathrm{K}$ ), the resulting value of $T \Delta S_{\text {sub }}$ is not large enough to cancel the positive $\Delta H_{\text {sub. }}$ Thus, the $\Delta G_{\text {sub }}\left(=\Delta H_{\text {sub }}-T \Delta S_{\text {sub }}\right)$ is still positive, and the $0.5 \mathrm{Zr}^{4+}+\mathrm{Si}^{4+} \rightarrow 0.5 \mathrm{U}^{6+}+\mathrm{Fe}^{3+}$ substitution, as written involving the direct substitution of binary oxides, is thermodynamically unfavorable at room temperature.

However, in natural conditions, the associated mineral compositions and reactions probably deviate from those indicated in reaction (1). In particular, $\mathrm{Fe}_{2} \mathrm{O}_{3}, \mathrm{UO}_{3}$, and $\mathrm{SiO}_{2}$ are unlikely to exist as separate phases but rather are incorporated in other minerals and present in aqueous solution, making their thermodynamic activities deviate from unity. In addition, elbrusite-(Zr) with an nominal composition of $\left.\mathrm{Ca}_{3}\left(\mathrm{U}^{6+} \mathrm{Zr}\right)\left(\mathrm{Fe}^{3+}{ }_{2} \mathrm{Fe}^{2+}\right) \mathrm{O}_{12}\right)$ is radioactive $(\sim 0.04$ displacement per atom), (Galuskina et al., 2010) which may cause radiation-induced reduction (Utsunomiya et al., 2005). Furthermore, some iron garnets can form in extremely reducing environments (Utsunomiya et al., 2005). Therefore, to assess the stability of $\mathrm{Ca}_{3}\left(\mathrm{U}_{x} \mathrm{Zr}_{2-x}\right) \mathrm{Fe}_{3} \mathrm{O}_{12}$ at reducing conditions, we change the $\mathrm{Fe}$ oxide in reaction (1) from $\mathrm{Fe}_{2} \mathrm{O}_{3}$ to $\mathrm{FeO}$ :

$$
\begin{aligned}
& \mathrm{Ca}_{3} \mathrm{Zr}_{2} \mathrm{SiFe}_{2} \mathrm{O}_{12\left(\mathrm{~s}, 25^{\circ} \mathrm{C}\right)}+x \gamma-\mathrm{UO}_{3\left(\mathrm{~s}, 25^{\circ} \mathrm{C}\right)}+\mathrm{FeO}_{\left(\mathrm{s}, 25^{\circ} \mathrm{C}\right)}+(1-x) / 2 \mathrm{O}_{2\left(\mathrm{~g}, 25^{\circ} \mathrm{C}\right)} \rightarrow \mathrm{Ca}_{3}\left(\mathrm{U}_{x} \mathrm{Zr}_{2-}\right. \\
& \left.{ }_{x}\right) \mathrm{Fe}_{3} \mathrm{O}_{12\left(\mathrm{~s}, 25^{\circ} \mathrm{C}\right)}+x \mathrm{ZrO}_{2\left(\mathrm{~s}, 25^{\circ} \mathrm{C}\right)}+\mathrm{SiO}_{2\left(\mathrm{~s}, 25^{\circ} \mathrm{C}\right)}
\end{aligned}
$$

As shown in Table 3, the enthalpies of reaction (2), $\Delta H_{\text {sub }}$, are all negative. The entropy changes are expected to be negative as well, which makes the free energies less negative but does not 
change their exothermic character. Detailed calculations of the entropy terms will be elucidated below. Thus, the formation of $\mathrm{Ca}_{3}\left(\mathrm{U}_{x} \mathrm{Zr}_{2-x}\right) \mathrm{Fe}_{3} \mathrm{O}_{12}$ due to the $0.5 \mathrm{Zr}^{4+}+\mathrm{Si}^{4+} \rightarrow 0.5 \mathrm{U}^{6+}+\mathrm{Fe}^{3+}$ substitution under reducing conditions may be thermodynamically favorable. In nature, however, because of the complex scenarios related to different minerals and conditions, the thermodynamic behavior of substituted garnets may vary from being stable to being unstable, as implied by reaction (2) and (1), respectively. Under both reducing and oxidizing conditions, the activities of oxide components will deviate from unity, affecting the free energy and extent of substitution. In addition, once a garnet forms, it may be slow to decompose and may persist metastably for long periods of time. The important point is that the thermochemical data suggest that uranium substitution in garnet may be favorable under a variety of conditions.

\subsection{Energetics of formation of $\mathrm{Ca}_{3}\left(\mathrm{U}_{x} \mathrm{Zr}_{2-x}\right) \mathrm{Fe}_{3} \mathrm{O}_{12}$ at $800{ }^{\circ} \mathrm{C}$}

Since the composition of $\mathrm{Ca}_{3}\left(\mathrm{U}_{x} \mathrm{Zr}_{2-x}\right) \mathrm{Fe}_{3} \mathrm{O}_{12}$ is close to that of natural elbrusite- $(\mathrm{Zr})$, $\mathrm{Ca}_{3}\left(\mathrm{U}^{6+} \mathrm{Zr}\right)\left(\mathrm{Fe}^{3+}{ }_{2} \mathrm{Fe}^{2+}\right) \mathrm{O}_{12}$, studying its energetics can facilitate our understanding of the formation of elbrusite-(Zr) at geological conditions. Galuskina et al. (Galuskina et al., 2010) demonstrated that elbrusite-( $\mathrm{Zr})$ can form at $800-1000{ }^{\circ} \mathrm{C}$ as a result of the explosive eruption of ignimbrites. As $\mathrm{U}_{3} \mathrm{O}_{8}$ is the only stable uranium oxide phase in this temperature range in air, we consider the following substitution reaction at $800{ }^{\circ} \mathrm{C}$, in which $\mathrm{U}_{3} \mathrm{O}_{8}$, instead of $\gamma-\mathrm{UO}_{3}$ or $\mathrm{UO}_{2}$, reacts with $\mathrm{Ca}_{3} \mathrm{Zr}_{2} \mathrm{SiFe}_{2} \mathrm{O}_{12}$ and $\mathrm{Fe}_{2} \mathrm{O}_{3}$ :

$\mathrm{Ca}_{3} \mathrm{Zr}_{2} \mathrm{SiFe}_{2} \mathrm{O}_{12\left(\mathrm{~s}, 800{ }^{\circ} \mathrm{C}\right)}+x / 3 \mathrm{U}_{3} \mathrm{O}_{8\left(\mathrm{~s}, 800{ }^{\circ} \mathrm{C}\right)}+1 / 2 \mathrm{Fe}_{2} \mathrm{O}_{3\left(\mathrm{~s}, 800{ }^{\circ} \mathrm{C}\right)}+(1 / 4-x / 3) \mathrm{O}_{2\left(\mathrm{~g}, 800{ }^{\circ} \mathrm{C}\right)} \rightarrow$

$\left.\left.\mathrm{Ca}_{3}\left(\mathrm{U}_{x} \mathrm{Zr}_{2-x}\right) \mathrm{Fe}_{3} \mathrm{O}_{12(\mathrm{~s},} \quad 800 \quad{ }^{\circ} \mathrm{C} \quad+\quad x \quad \mathrm{ZrO}_{2(\mathrm{~s},} \quad 800 \quad{ }^{\circ} \mathrm{C}\right) \quad+\quad \mathrm{SiO}_{2(\mathrm{~s},} \quad 800 \quad{ }^{\circ} \mathrm{C}\right)$ 
The enthalpies of reaction (3) $\left(\Delta H^{800^{\circ} \mathrm{C}}\right.$ sub"') were calculated using the thermochemical cycles in Table S6 in SI. As shown in Table 3, only the phase with the maximum U substitution, $x=0.7$, has a negative value of $\Delta H^{800{ }^{\circ} \mathrm{C}}$ sub", $-19.7 \pm 5.3 \mathrm{~kJ} / \mathrm{mol}$, However, in determining thermodynamic stability at high temperature, the contribution from changes in entropy, $\Delta S_{\text {sub }}$ " $=\Delta S^{800{ }^{\circ} \mathrm{C}}{ }_{\text {th }}+\Delta S_{\text {conf }}$ (Table 3), must be considered. The first entropy term, $\Delta S^{800{ }^{\circ} \mathrm{C}}{ }_{\text {th }}$, decreases by $246.1 \mathrm{~J} / \mathrm{mol} \cdot \mathrm{K}$ per mole of reacted $\mathrm{O}_{2}$ (Chase, 1998), where the small vibrational entropy differences between the solid reactants and products can be neglected. The second term, $\Delta S_{\text {conf }}$, reflects the change in configurational entropy between $\mathrm{Ca}_{3} \mathrm{Zr}_{2} \mathrm{SiFe}_{2} \mathrm{O}_{12}$ and $\mathrm{Ca}_{3}\left(\mathrm{U}_{x} \mathrm{Zr}_{2-x}\right) \mathrm{Fe}_{3} \mathrm{O}_{12}$. Specifically, the $\Delta S_{\text {conf }}$ values are calculated from random distributions of $\mathrm{Si}^{4+}$ and $\mathrm{Fe}^{3+}$ over the tetrahedral sites in $\mathrm{Ca}_{3} \mathrm{Zr}_{2} \mathrm{SiFe}_{2} \mathrm{O}_{12}$; and of $\mathrm{U}^{5+}$ and $\mathrm{Zr}^{4+}$ or $\mathrm{U}^{6+}, \mathrm{U}^{5+}$ and $\mathrm{Zr}^{4+}$ over the octahedral sites, and $\mathrm{Fe}^{2+}$ and $\mathrm{Fe}^{3+}$ over the tetrahedral sites in $\mathrm{Ca}_{3}\left(\mathrm{U}_{x} \mathrm{Zr}_{2-x}\right) \mathrm{Fe}_{3} \mathrm{O}_{12}$. The distribution of cations with different oxidation states is based on results from XPS analysis, described earlier. The total configuration entropy change can be calculated as follows:

$$
\begin{aligned}
\Delta S_{\text {conf }}= & \Delta S_{\text {conf }}\left(\mathrm{U}^{6+}, \mathrm{U}^{5+}, \mathrm{Zr}^{4+}\right)+\Delta S_{\text {conf }}\left(\mathrm{Fe}^{3+}, \mathrm{Fe}^{2+}\right)-\Delta S_{\text {conf }}\left(\mathrm{Si}^{4+}, \mathrm{Fe}^{3+}\right) \\
= & -2 \mathrm{R}[(2-x) / 2 \cdot(\ln (2-x) / 2)+x / 2 \ln (x / 2)] \\
& -x \mathrm{R}[y \ln y+(1-y) \ln (1-y)]-3 \mathrm{R}[z \ln z+(1-z) \ln (1-z)] \\
& +3 \mathrm{R}[2 / 3 \cdot \ln (2 / 3)+1 / 3 \cdot \ln (1 / 3)]
\end{aligned}
$$

where $x$ is the $\mathrm{U}$ concentration in apfu and $y$ is the fraction of $\mathrm{U}^{5+}$ to total $\mathrm{U}$. As temperature increases, the entropic contribution, $-T \Delta S_{\text {sub }}$ ", becomes larger in magnitude, specifically for the $x$ $=0.7$ phase, its positive $\Delta S_{\text {sub }}$ " further lowers the free energy of substitution $\left(\Delta G^{800{ }^{\circ} \mathrm{C}}{ }_{\text {sub }} ",=\Delta H^{800}\right.$ ${ }^{\circ}{ }_{\text {sub }}$ " - $T \Delta S_{\text {sub }}$, Table 3) by $8.7 \mathrm{~kJ} / \mathrm{mol}$, resulting in a $\Delta G^{800{ }^{\circ} \mathrm{C}}$ sub" of $-28.4 \pm 5.3 \mathrm{~kJ} / \mathrm{mol}$. Hence, the formation of $\mathrm{Ca}_{3}\left(\mathrm{U}_{0.7} \mathrm{Zr}_{1.3}\right) \mathrm{Fe}_{3} \mathrm{O}_{12}$ is thermodynamically favorable at $800{ }^{\circ} \mathrm{C}$. This conclusion 
is consistent with the occurrence of elbrusite- $(\mathrm{Zr})$ in nature, considering that it has 0.658 apfu of $\mathrm{U}$ (Galuskina et al., 2010), close to that of $\mathrm{Ca}_{3}\left(\mathrm{U}_{0.7} \mathrm{Zr}_{1.3}\right) \mathrm{Fe}_{3} \mathrm{O}_{12}(0.7$ apfu U). Again, changes in the activities of oxide components in the igneous system will affect the free energy balance, but the overall conclusion of likely stability is likely to remain valid.

\subsection{Energetics of the substitution in $\mathrm{Ca}_{3}\left(\mathrm{U}_{x} \mathrm{Zr}_{2-x}\right) \mathrm{Fe}_{3} \mathrm{O}_{12}$ garnets}

The incorporation of $\mathrm{U}$ in this series of garnets starts from the substitution of all the $\mathrm{Si}$ atoms in $\mathrm{Ca}_{3} \mathrm{Zr}_{2} \mathrm{SiFe}_{2} \mathrm{O}_{12}$ by $\mathrm{Fe}$ to form $\mathrm{Ca}_{3}\left(\mathrm{U}_{x} \mathrm{Zr}_{2-x}\right) \mathrm{Fe}_{3} \mathrm{O}_{12}$ with 0.5 apfu $\mathrm{U}(x=0.5)$. With increasing $\mathrm{U}$ content from $x=0.5$ to 0.7 , we observe a trend of increased stability. A general reaction describing $\mathrm{U}$ substitution from $x$ apfu to $x$ ' apfu can be represented as:

$$
\begin{aligned}
& \mathrm{Ca}_{3}\left(\mathrm{U}_{x} \mathrm{Zr}_{2-x}\right) \mathrm{Fe}_{3} \mathrm{O}_{12\left(\mathrm{~s}, 25^{\circ} \mathrm{C}\right)}+\left(x^{\prime}-x\right) \gamma-\mathrm{UO}_{3\left(\mathrm{~s}, 25^{\circ} \mathrm{C}\right)} \rightarrow \quad \mathrm{Ca}_{3}\left(\mathrm{U}_{x}, \mathrm{Zr}_{2-x^{\prime}}\right) \mathrm{Fe}_{3} \mathrm{O}_{12\left(\mathrm{~s}, 25^{\circ} \mathrm{C}\right)}+\left(x^{\prime}-x\right) \\
& \mathrm{ZrO}_{2\left(\mathrm{~s}, 25^{\circ} \mathrm{C}\right)}+\left(x^{\prime}-x\right) / 2 \mathrm{O}_{2\left(\mathrm{~g}, 25^{\circ} \mathrm{C}\right)}
\end{aligned}
$$

The enthalpies of reaction (5) for $x=0.5 \rightarrow 0.6$ and $x=0.6 \rightarrow 0.7$ are calculated to be $-12.8 \pm 3.4$, and $-23.5 \pm 2.8 \mathrm{~kJ} / \mathrm{mol}$, respectively. Thus the stability of $\mathrm{Ca}_{3}\left(\mathrm{U}_{x} \mathrm{Zr}_{2-x}\right) \mathrm{Fe}_{3} \mathrm{O}_{12}$ increases with increasing $\mathrm{U}$ content. In other words, once the $\mathrm{Ca}_{3}\left(\mathrm{U}_{x} \mathrm{Zr}_{2-x}\right) \mathrm{Fe}_{3} \mathrm{O}_{12}$ phase with a higher $\mathrm{U}$ content forms, the phase will be more stable and have a lower thermodynamic driving force to decompose into U(VI) oxide, which is more soluble at aqueous conditions.

The thermodynamics of reaction (5) suggests a possible pathway for $\mathrm{Ca}_{3}\left(\mathrm{U}_{x} \mathrm{Zr}_{2-x}\right) \mathrm{Fe}_{3} \mathrm{O}_{12}$ to transform to phases with higher U concentrations in natural environments; however, this does not reflect the changes in structural energetics $\left(\Delta H_{\text {inc }}\right)$ arising from substitution of cations with different sizes. If we subtract the effects of $\mathrm{U}^{6+} \rightarrow \mathrm{U}^{5+}$ and $\mathrm{Fe}^{3+} \rightarrow \mathrm{Fe}^{2+}$ reductions, we can estimate the enthalpy change due to the cation substitution represented by: 
${ }^{\mathrm{VI}} \mathrm{Zr}^{4+}+y{ }^{,{ }^{\mathrm{IV}}} \mathrm{U}^{6+}+z,{ }^{\mathrm{IV}} \mathrm{Fe}^{3+}={ }^{\mathrm{IV}} \mathrm{U}^{6+}+y,{ }^{, \mathrm{VI}} \mathrm{U}^{5+}+z{ }^{, \mathrm{IV}} \mathrm{Fe}^{2+}$

where $y^{\prime}=x^{\prime} y /\left(x^{\prime}-x\right)$ and $z^{\prime}=z /\left(x^{\prime}-x\right)$, in which $z$ is the fraction of $\mathrm{Fe}^{2+}$ of the total $\mathrm{Fe}$. The enthalpy of reduction $\left(\Delta H_{\text {red }}\right)$ of $\mathrm{U}^{6+} \rightarrow \mathrm{U}^{5+}$ is $67.8 \mathrm{~kJ} / \mathrm{mol}$, and that of $\mathrm{Fe}^{3+} \rightarrow \mathrm{Fe}^{2+}$ is 147.3 $\mathrm{kJ} / \mathrm{mol}$ (Robie and Hemingway, 1995). In each step of the substitution, depending on the configuration of oxidation states of $\mathrm{U}$ and Fe, the total $\Delta H_{\text {red }}$ varies from $13.6 \mathrm{~kJ} / \mathrm{mol}$ in the case of no $\mathrm{Fe}^{2+}$ to $21.5 \mathrm{~kJ} / \mathrm{mol}$ in the case of 0.1 apfu $\mathrm{Fe}^{2+}$. Thus the enthalpies of structural substitution $\left(\Delta H_{\text {inc }}=\Delta H_{\text {sub }}-\Delta H_{\text {red }}\right)$ are negative, suggesting that $\mathrm{Ca}_{3}\left(\mathrm{U}_{x} \mathrm{Zr}_{2-x}\right) \mathrm{Fe}_{3} \mathrm{O}_{12}$ gains more thermodynamic stability at higher $U$ concentrations. This trend may arise from the attenuation of lattice strain (Guo et al., 2014a) in the expanded, U/Fe-substituted garnet structure. The presence of larger $\mathrm{U}^{5+}(0.76 \AA)$, compared to $\mathrm{U}^{6+}(0.73 \AA)$ and $\mathrm{Zr}^{4+}(0.72 \AA)$, expands the octahedral sublattice so that $\mathrm{U}-\mathrm{O}$ and $\mathrm{Zr}-\mathrm{O}$ bonds can relax towards their strain-free bonding environments, as observed by EXAFS. On the other hand, the larger $\mathrm{Fe}^{2+}$ on the tetrahedral sites may increase the strain energy and thus is likely unfavorable, as evidenced from Mössbauer spectroscopy results. This may also explain why the garnet structure prefers to contain more reduced $\mathrm{U}$ rather than reduced Fe. These somewhat speculative explanations could benefit from further investigation of the electronic structures of these garnets by both calculations and experiment.

\section{Conclusion}

$\mathrm{Ca}_{3}\left(\mathrm{U}_{x} \mathrm{Zr}_{2-x}\right) \mathrm{Fe}_{3} \mathrm{O}_{12}$ garnets exhibit good isomorphic capacity of incorporating significant amounts of U. Oxidation states of U were investigated by XPS and XAS, from which evidence for the presence of $\mathrm{U}^{5+}$ in $\mathrm{Ca}_{3}\left(\mathrm{U}_{x} \mathrm{Zr}_{2-x}\right) \mathrm{Fe}_{3} \mathrm{O}_{12}$ with $x=0.6$ and 0.7 was obtained. Mössbauer spectroscopy confirmed the oxidation state of Fe to be mostly trivalent. Quantitative results of oxidation states of $\mathrm{U}$ and $\mathrm{Fe}$ were used together with calorimetrically measured enthalpies of drop solution in the lead borate solvent to derive standard enthalpies of formation. 
Our thermodynamic analysis shows that the reaction from $\mathrm{Ca}_{3}\left(\mathrm{Zr}_{2}\right) \mathrm{SiFe}_{2} \mathrm{O}_{12}$ to $\mathrm{Ca}_{3}\left(\mathrm{U}_{x} \mathrm{Zr}_{2-}\right.$ $\left.{ }_{x}\right) \mathrm{Fe}_{3} \mathrm{O}_{12}$ garnet is energetically favorable at high temperatures (e.g., $800{ }^{\circ} \mathrm{C}$ ). This conclusion helps explain the occurrence of natural U-bearing garnet, elbrusite-(Zr), during volcanic events such as the explosive eruption of ignimbrites. The high stability of U-containing garnets with respect to the constituent oxides may imply their long term persistence under various geological conditions. Further thermodynamic analysis shows that $\mathrm{Ca}_{3}\left(\mathrm{U}_{x} \mathrm{Zr}_{2-x}\right) \mathrm{Fe}_{3} \mathrm{O}_{12}$ garnet is energetically favorable under reducing conditions and has improved stability with increasing U content. These finding may lead to strategies for utilizing U-substituted garnets for actinide waste disposal. Future studies should explore the stability of these garnets with respect to other possible mineral assemblages.

\section{Acknowledgements}

This work was supported by the Materials Science of Actinides, an Energy Frontier Research Center funded by the U.S. Department of Energy (US-DOE), Office of Science, Office of Basic Energy Sciences under Award Number DE-SC0001089. The Mössbauer spectroscopic and XPS analysis were performed using Environmental Molecular Sciences Laboratory (EMSL), a DOE Office of Science User Facility sponsored by the Office of Biological and Environmental Research and located at Pacific Northwest National Laboratory. PNNL is operated by Battelle for the U.S. DOE under contract DE-AC06-76RLO1930. The synchrotron XAS work was performed at GeoSoilEnviroCARS (Sector 13), Advanced Photon Source (APS), Argonne National Laboratory. GeoSoilEnviroCARS is supported by the National Science Foundation - Earth Sciences (EAR-1128799) and Department of Energy - GeoSciences (DE-FG02-94ER14466). Use of the Advanced Photon Source was supported by the U. S. Department of Energy, Office of 
Science, Office of Basic Energy Sciences, under Contract No. DE-AC02-06CH11357. The last stages of this work was also supported by the laboratory-directed research and development (LDRD) program, through the G. T. Seaborg Institute, of Los Alamos National Laboratory, which is operated by Los Alamos National Security LLC, under DOE Contract DE-AC52-06NA25396, in that X.G. is now pursuing a Seaborg postdoctoral fellowship at LANL. We thank A.H. Tavakoli for participation in the initial stages of this project and P.S. Maram for helpful discussions. 


\section{References}

Burakov B.E., Anderson E.B., Knecht D.A., Zamoryanskaya M.A., Strykanova E.E., and Yagovkina M.A. (1999) Synthesis of garnet/perovskite-based ceramic for the immobilization of Pu-residue wastes. Mater. Res. Soc. Symp. Proc. 556, 6.

Burakov B.E., Anderson E.B., Zamoryanskaya M.A., and Petrova M.A. (2000) Synthesis and study of ${ }^{239} \mathrm{Pu}$-doped gadolinium-aluminum garnet. Mater. Res. Soc. Symp. Proc. 608, 4.

Burakov B.E. and Strykanova E.E. (1998) Garnet solid solution of $\mathrm{Y}_{3} \mathrm{Al}_{5} \mathrm{O}_{12}-\mathrm{Gd}_{3} \mathrm{Ga}_{5} \mathrm{O}_{12^{-}}$ $\mathrm{Y}_{3} \mathrm{Ga}_{5} \mathrm{O}_{12}$ (YAGGGGYGG) as a prospective crystalline host-phase for $\mathrm{Pu}$ immobilization in the presence of Ga, WM'98 Proceedings, Tucson, AZ, United States, pp. 1254-1258.

Chase M.W.J. (1998) NIST-JANAF Thermochemical Tables, Fourth Edition. J. Phys. Chem. Ref. Data Monograph 9, 1-1951.

Cheng J.H. and Navrotsky A. (2005) Energetics of $\mathrm{La}_{1-\mathrm{x}} \mathrm{A}_{\mathrm{x}} \mathrm{CrO}_{3-\delta}$ perovskites $(\mathrm{A}=\mathrm{Ca}$ or $\mathrm{Sr}$ ). $J$. Solid State Chem. 178, 234-244.

Cordfunke E.H.P. and Loopstra B.O. (1967) Preparation and properties of uranates of calcium and strontium. J. Inorg. Nucl. Chem. 29, 51-57.

Ewing R.C. (1999) Nuclear waste forms for actinides. Proc. Natl. Acad. Sci. USA 96, 3432-3439.

Ewing R.C. (2006) The nuclear fuel cycle: A role for mineralogy and geochemistry. Elements 2, $331-334$

Ewing R.C., Weber W.J. and Lian J. (2004) Nuclear waste disposal-pyrochlore $\left(\mathrm{A}_{2} \mathrm{~B}_{2} \mathrm{O}_{7}\right)$ : Nuclear waste form for the immobilization of plutonium and "minor" actinides. J. Appl. Phys. 95, 5949-5971.

Galuskina I.O., Galuskin E.V., Armbruster T., Lazic B., Kusz J., Dzierzanowski P., Gazeev V.M., Pertsev N.N., Prusik K., Zadov A.E., Winiarski A., Wrzalik R. and Gurbanov A.G. (2010) Elbrusite-(Zr)-A new uranian garnet from the Upper Chegem caldera, Kabardino-Balkaria, Northern Caucasus, Russia. Am. Mineral. 95, 1172-1181. 
Galuskina I.O., Gazeev V.M. and Galuskin E.V. (2008) Proc. of 2th International symposium Uranium: resources and production, Moscow, pp. 31.

Geller S. (1967) Crystal Chemistry of Garnets. Z. Kristallogr. Krist. 125, 4-5.

Gibbs G.V. and Smith J.V. (1965) Refinement of crystal structure of synthetic pyrope. Am. Mineral. 50, 2023.

Grambow B. (2006) Nuclear waste glasses - How durable? Elements 2, 357-364.

Gramsch S.A. and Morss L.R. (1994) Synthesis and characterization of charge-substituted garnets $\mathrm{YCaLnGa}_{5} \mathrm{O}_{12}(\mathrm{Ln}=\mathrm{Ce}, \mathrm{Pr}, \mathrm{Tb})$. J. Alloy. Compd. 207, 432-435.

Guo X., Kukkadapu R.K., Lanzirotti A., Newville M., Engelhard M.H., Sutton S.R. and Navrotsky A. (2015a) Charge-coupled substituted garnets $\left(\mathrm{Y}_{3-\mathrm{x}} \mathrm{Ca}_{0.5 \mathrm{x}} \mathrm{M}_{0.5 \mathrm{x}}\right) \mathrm{Fe}_{5} \mathrm{O}_{12}(\mathrm{M}=\mathrm{Ce}$, Th): structure and stability as crystalline nuclear waste forms. Inorg. Chem. 54, 4156-4166.

Guo X., Szenknect S., Mesbah A., Labs S., Clavier N., Poinssot C., Ushakov S.V., Curtius H., Bosbach D., Ewing R.C., Burns P.C., Dacheux N. and Navrotsky A. (2015b) Thermodynamics of formation of coffinite, $\mathrm{USiO}_{4}$. Proc. Natl. Acad. Sci. USA 112, 6551-6555.

Guo X., Tavakoli A.H., Sutton S., Kukkadapu R.K., Qi L., Lanzirotti A., Newville M., Asta M. and Navrotsky A. (2014a) Cerium substitution in yttrium iron garnet: valence state, structure, and energetics. Chem. Mater. 26, 1133-1143.

Guo, X., Tiferet, E., Qi, L., Solomon, J.M., Lanzirotti, A., Newville, M., Engelhard, M.H., Kukkadapu, R.K., Wu, D., Ilton, E.S., Asta, M., Sutton, S., Xu, H. and Navrotsky, A. (2016) $\mathrm{U}(\mathrm{V})$ in metal uranates: a combined experimental and theoretical study of $\mathrm{MgUO}_{4}, \mathrm{CrUO}_{4}$ and FeUO $_{4}$. Dalton Trans. 45, 4622-4632.

Guo X., Ushakov S.V., Labs S., Curtius H., Bosbach D. and Navrotsky A. (2014b) Energetics of metastudtite and implications for nuclear waste alteration. Proc. Natl. Acad. Sci. USA 111, $17737-17742$. 
Guo X., Rak Z., Tavakoli A.H., Becker U., Ewing R.C. and Navrotsky A. (2014c) Thermodynamics of thorium substitution in yttrium iron garnet: comparison of experimental and theoretical results. J. Mater. Chem. A 2, 16945-16954.

Guo X.Z., Ravi B.G., Devi P.S., Hanson J.C., Margolies J., Gambino R.J., Parise J.B. and Sampath S. (2005) Synthesis of yttrium iron garnet (YIG) by citrate-nitrate gel combustion and precursor plasma spray processes. J. Magn. Magn. Mater. 295, 145-154.

Helean K.B., Navrotsky A., Vance E.R., Carter M.L., Ebbinghaus B., Krikorian O., Lian J., Wang L.M. and Catalano J.G. (2002) Enthalpies of formation of Ce-pyrochlore, $\mathrm{Ca}_{0.93} \mathrm{Ce}_{1.00} \mathrm{Ti}_{2.035} \mathrm{O}_{7.00}, \quad$ U-pyrochlore, $\mathrm{Ca}_{1.46} \mathrm{U}_{0.234+} \mathrm{U}_{0.466+} \mathrm{Ti}_{1.85} \mathrm{O}_{7.00}$ and Gd-pyrochlore, $\mathrm{Gd}_{2} \mathrm{Ti}_{2} \mathrm{O}_{7}$ : three materials relevant to the proposed waste form for excess weapons plutonium. J. Nucl. Mater. 303, 226-239.

Kesson S.E. and Ringwood A.E. (1983) Safe Disposal of Spent Nuclear-Fuel. Radioact. Waste Manag. 4, 159-174.

Kum J.S., Kim S.J., Shim I.B. and Kim C.S. (2004) Mossbauer studies and magnetic properties of $\mathrm{Y}_{3-\mathrm{x}} \mathrm{Ce}_{\mathrm{x}} \mathrm{Fe}_{5} \mathrm{O}_{12}$. Hyperfine Interact. 156, 169-174.

Laverov N.P., Velichkin V.I., Omel'yanenko B.I., et al. (2008) Isolation of spent nuclear materials: geological and geochemical aspects. IFZ RAN, Moscow.

Laverov N.P., Yudintsev S.V., Livshits T.S., Stefanovsky S.V., Lukinykh A.N. and Ewing R.C. (2010) Synthetic minerals with the pyrochlore and garnet structures for immobilization of actinide-containing wastes. Geochem. Int. 48, 1-14.

Laverov N.P., Yudintsev S.V., Yudintseva T.S., Stefanovsky S.V., Ewing R.C., Lian J., Utsunomiya S. and Wang L.A. (2003) Effect of radiation on properties of confinement matrices for immobilization of actinide-bearing wastes. Geol. Ore Deposit 45, 423-451.

Lee T.A., Navrotsky A. and Molodetsky I. (2003) Enthalpy of formation of cubic yttria-stabilized zirconia. J. Mater. Res. 18, 908-918. 
Lilova K.I., Xu F., Rosso K.M., Pearce C.I., Kamali S. and Navrotsky A. (2012) Oxide melt solution calorimetry of Fe-bearing oxides and application to the magnetite-maghemite $\left(\mathrm{Fe}_{3} \mathrm{O}_{4}-\right.$ $\left.\mathrm{Fe}_{8 / 3} \mathrm{O}_{4}\right)$ system. Am. Mineral. 97, 164-175.

Livshits T.S. (2008) Stability of artificial ferrite garnets with actinides and lanthanoids in water solutions. Geol. Ore Deposit 50, 470-481.

Lumpkin G.R. (2006) Ceramic waste forms for actinides. Elements 2, 365-372.

Lutze W. and Ewing R.C. (1988) Radioactiv waste forms for the future. Elsevier, Amsterdam.

Mazeina L., Ushakov S.V., Navrotsky A. and Boatner L.A. (2005) Formation enthalpy of $\mathrm{ThSiO}_{4}$ and enthalpy of the thorite $\rightarrow$ huttonite phase transition. Geochim. Cosmochim. Acta 69, 46754683.

Navrotsky A. (1977) Progress and new directions in high-temperature calorimetry. Phys. Chem. Miner. 2, 89-104.

Navrotsky A. (1997) Progress and new directions in high temperature calorimetry revisited. Phys. Chem. Miner. 24, 222-241.

Navrotsky A. (2014) Progress and new directions in calorimetry: a 2014 perspective. J. Am. Cera. Soc. 97, 3349-3359.

Navrotsky A., Rapp R.P., Smelik E., Burnley P., Circone S., Chai L. and Bose K. (1994) The behavior of $\mathrm{H}_{2} \mathrm{O}$ and $\mathrm{CO}_{2}$ in high-temperature lead borate solution calorimetry of volatilebearing phases. Am. Mineral. 79, 1099-1109.

Navrotsky A., Shvareva T. and Guo X. (2013) Thermodynamics of uranium minerals and related materials, in: Burns P.C. and Sigmon G.E. (Eds.) Uranium - Cradle to Grave. Mineralogical Association of Canada, Winnipeg, MB, Cananda, pp. 147-164.

Novak G.A. and Gibbs G.V. (1971) Crystal chemistry of silicate garnets. Am. Mineral. 56, 791.

Omel'yanenko B.I., Livshits T.S., Yudintsev S.V. and Nikonov B.S. (2007) Natural and artificial minerals as matrices for immobilization of actinides. Geol. Ore Deposit 49, 173-193. 
Peretyazhko T.S., Zachara J.M., Kukkadapu R.K., Heald S.M., Kutnyakov I.V., Resch C.T., Arey B.W., Wang C.M., Kovarik L., Phillips J.L. and Moore D.A. (2012) Pertechnetate (TcO $\left.{ }^{4-}\right)$ reduction by reactive ferrous iron forms in naturally anoxic, redox transition zone sediments from the Hanford Site, USA. Geochim. Cosmochim. Ac. 92, 48-66.

Rak Z., Ewing R.C. and Becker U. (2011) Role of iron in the incorporation of uranium in ferric garnet matrices. Phys. Rev. B: Condens. Matter Mater. Phys. 84, 155128/155121$155128 / 155110$.

Rak Z., Ewing R.C. and Becker U. (2013a) Electronic structure and thermodynamic stability of uranium-doped yttrium iron garnet. J. Phys.-Condens. Mat. 25, 495502.

Rak Z., Ewing R.C. and Becker U. (2013b) Ferric garnet matrices for immobilization of actinides. J. Nucl. Mater. 436, 1-7.

Ravel B. and Newville M. (2005) ATHENA, ARTEMIS, HEPHAESTUS: data analysis for X-ray absorption spectroscopy using IFEFFIT. J. Synchrotron Radiat. 12, 537-541.

Rettenwander D., Geiger C.A., Tribus M., Tropper P., Wagner R., Tippelt G., Lottermoser W. and Amthauer G. (2015) The solubility and site preference of $\mathrm{Fe}^{3+}$ in $\mathrm{Li}_{7-3 x} \mathrm{Fe}_{\mathrm{x}} \mathrm{La}_{3} \mathrm{Zr}_{2} \mathrm{O}_{12}$ garnets. J. Solid State Chem. 230, 266-271.

Rietveld H.M. (1969) A profile refinement method for nuclear and magnetic structures. J. Appl. Crystallogr. 2, 65.

Ringwood T. (1982) Immobilization of radioactive-wastes in synroc. Am. Sci. 70, 201-207.

Robie R.A. and Hemingway B.S. (1995) Thermodynamic properties of minerals and related substances at $298.15 \mathrm{~K}$ and 1 bar pressure and at higher temperatures.

Rusakov V.S., Urusov V.S., Kovalchuk R.V., Kabalov Y.K. and Yudincev S.V. (2005) Mossbauer study of ferrite-garnets as matrixes for disposal of highly radioactive waste products. Hyperfine Interact. 164, 99-104. 
Sinclair W. and Ringwood A.E. (1981) Alpha-recoil damage in natural zirconolite and perovskite. Geochem. J. 15, 229-243.

Soldatov A.V., Lamoen D., Konstantinovic M.J., Van d.B.S., Scheinost A.C. and Verwerft M. (2007) Local structure and oxidation state of uranium in some ternary oxides: X-ray absorption analysis. J. Solid State Chem. 180, 54-61.

Stefanovsky S.V., Yudintsev S.V. and Livshits T.S. (2010) New cubic structure compounds as actinide host phases IOP Conference Series: Materials Science and Engineering 9, 12.

Urusov V.S., Organova N.I., Karimova O.V., Yudintsev S.V. and Stefanovskii S.V. (2005) Synthetic "murataites" as modular members of a pyrochlore-murataite polysomatic series. Dokl. Earth Sci. 401, 319-325.

Urusov V.S., Rusakov V.S., Kabalov Y.K. and Yudintsev S.V. (2004) Tetragonalization of $\left(\mathrm{Ca}_{3}\right.$ $\left.{ }_{x} \mathrm{~A}_{\mathrm{x}}\right)\left(\mathrm{Zr}_{2-\mathrm{y}} \mathrm{Fe}_{\mathrm{y}}\right) \mathrm{Fe}_{3} \mathrm{O}_{12}(\mathrm{~A}=\mathrm{Ce}, \mathrm{Th}, \mathrm{Gd})$ ferrite garnets as revealed by Mossbauer spectroscopy and the Rietveld analysis. Dokl. Phys. 49, 715-722.

Utsunomiya S., Wang L.M. and Ewing R.C. (2002a) Ion irradiation effects in natural garnets: Comparison with zircon. Nucl. Instrum. Meth. B 191, 600-605.

Utsunomiya S., Wang L.M., Yudintsev S. and Ewing R.C. (2002b) Ion irradiation-induced amorphization and nano-crystal formation in garnets. J. Nucl. Mater. 303, 177-187.

Utsunomiya S., Yudintsev S. and Ewing R.C. (2005) Radiation effects in ferrate garnet. J. Nucl. Mater. 336, 251-260.

Vajargah S.H., Hosseini H.R.M. and Nemati Z.A. (2007) Preparation and characterization of yttrium iron garnet (YIG) nanocrystalline powders by auto-combustion of nitrate-citrate gel. $J$. Alloy. Compd. 430, 339-343.

Vaqueiro P., CrosnierLopez M.P. and LopezQuintela M.A. (1996). Synthesis and characterization of yttrium iron garnet nanoparticles. J. Solid State Chem. 126, 161-168. 
Weber W.J., Ewing R.C., Angell C.A., Arnold G.W., Cormack A.N., Delaye J.M., Griscom D.L., Hobbs L.W., Navrotsky A., Price D.L., Stoneham A.M. and Weinberg W.C. (1997) Radiation effects in glasses used for immobilization of high-level waste and plutonium disposition. $J$. Mater. Res. 12, 1946-1978.

Weber W.J., Navrotsky A., Stefanovsky S., Vance E.R. and Vernaz E. (2009) Materials science of high-level nuclear waste immobilization. Mrs. Bull. 34, 46-53.

Youdintseva T.S. (2005) Study of synthetic ferrite garnets in context with the problem of immobilization of actinide wastes. Geol. Ore Deposit 47, 403-409.

Yudintsev S.V. (2003) A structural-chemical approach to selecting crystalline matrices for actinide immobilization. Geol. Ore Deposit 45, 151-165.

Yudintsev S.V., Lapina M.I., Ptashkin A.G., Ioudintseva T.S., Utsunomiya S., Wang L.M. and Ewing R.C. (2002) Accommodation of uranium into the garnet structure. Mater. Res. Soc. Symp. Proc. 713, 477-480.

Yudintsev S.V., Stefanovsky S.V. and Ewing R.C. (2007) Actinide host phases as radioactive waste forms, in: Krivovichev, S.V.B., P. C.; Tananaev, I. G. (Ed.), Structural Chemistry of Inorganic Actinide Compounds. Elsevier, Amsterdam, pp. 457-490.

Zaitsev A.N., Williams C.T., Britvin S.N., Kuznetsova I.V., Spratt J., Petrov S.V. and Keller, J. (2010) Kerimasite, $\mathrm{Ca}_{3} \mathrm{Zr}_{2}\left(\mathrm{Fe}_{2}{ }^{3+} \mathrm{Si}\right) \mathrm{O}_{12}$, a new garnet from carbonatites of Kerimasi volcano and surrounding explosion craters, northern Tanzania. Mineral. Mag. 74, 803-820.

Zamoryanskaya M.A. and Burakov B.E. (2000) Cathodoluminescence of Ce, U and Pu in a garnet host phase. Mater. Res. Soc. Symp. Proc. 608, 6.

Zhang J.M., Livshits T.S., Lizin A.A., Hu Q.N. and Ewing R.C. (2010) Irradiation of synthetic garnet by heavy ions and alpha-decay of Cm-244. J. Nucl. Mater. 407, 137-142. 


\section{Tables}

Table 1. Enthalpies of drop solution and enthalpies of formation of garnets from binary oxides and from elements at $25^{\circ} \mathrm{C}$.

\begin{tabular}{llll}
\hline Sample & $\Delta H_{\mathrm{ds}}(\mathrm{kJ} / \mathrm{mol})^{*}$ & $\Delta H_{\mathrm{f}, \mathrm{ox}}(\mathrm{kJ} / \mathrm{mol})^{\dagger}$ & $\Delta H_{\mathrm{f}}^{\mathrm{o}}(\mathrm{kJ} / \mathrm{mol})^{\ddagger}$ \\
\hline$x=0$ & $513.73 \pm 3.93(5)$ & $-137.0 \pm 8.2$ & $-5980.4 \pm 9.4$ \\
$x=0.5$ & $444.91 \pm 2.66(5)$ & $-55.1 \pm 8.0$ & $-5462.5 \pm 9.0$ \\
$x=0.6$ & $450.84 \pm 2.12(5)$ & $-67.9 \pm 7.9$ & $-5487.4 \pm 8.9$ \\
$x=0.7$ & $467.49 \pm 1.81(5)$ & $-91.5 \pm 8.0$ & $-5523.5 \pm 8.9$
\end{tabular}

* Uncertainty is two standard deviations of the average value; number in the parentheses is the number of measurements. ${ }^{\dagger}$ Data calculated from Table $2 .{ }^{\star}$ Data calculated from Table S5. 
Table 2. Thermochemical cycles for determination of the enthalpies of formation of garnets from binary oxides (based on drop solution calorimetry in molten $2 \mathrm{PbO} \cdot \mathrm{B}_{2} \mathrm{O}_{3}$ at $802{ }^{\circ} \mathrm{C}$ ).

\begin{tabular}{|c|c|}
\hline Reaction & $\Delta H(\mathrm{~kJ} / \mathrm{mol})$ \\
\hline$(1) \mathrm{Ca}_{3} \mathrm{Zr}_{2} \mathrm{SiFe}_{2} \mathrm{O}_{12\left(\mathrm{~s}, 25^{\circ} \mathrm{C}\right)} \rightarrow 3 \mathrm{CaO}_{\left(\mathrm{sln}, 802^{\circ} \mathrm{C}\right)}+2 \mathrm{ZrO}_{2\left(\sin , 802^{\circ} \mathrm{C}\right)}+\mathrm{SiO}_{2\left(\sin , 802^{\circ} \mathrm{C}\right)}+\mathrm{Fe}_{2} \mathrm{O}_{3\left(\sin , 802^{\circ} \mathrm{C}\right)}$ & $\Delta H_{1}=\Delta H_{\mathrm{ds}}$ \\
\hline (2) $\begin{array}{c}\mathrm{Ca}_{3}\left(\mathrm{U}_{x} \mathrm{Zr}_{2-x}\right) \mathrm{Fe}_{3} \mathrm{O}_{12\left(\mathrm{~s}, 25^{\circ} \mathrm{C}\right)}+(2 x-1) / 4 \mathrm{O}_{2\left(\mathrm{~g}, 802^{\circ} \mathrm{C}\right)} \rightarrow 3 \mathrm{CaO}_{\left(\mathrm{sln}, 802^{\circ} \mathrm{C}\right)}+x \mathrm{UO}_{3\left(\sin , 802^{\circ} \mathrm{C}\right)} \\
+(2-x) \mathrm{ZrO}_{2\left(\sin , 802^{\circ} \mathrm{C}\right)}+3 / 2 \mathrm{Fe}_{2} \mathrm{O}_{3\left(\sin , 802^{\circ} \mathrm{C}\right)}\end{array}$ & $\Delta H_{2}=\Delta H_{\mathrm{ds}}$ \\
\hline (3) $\gamma-\mathrm{UO}_{3\left(\mathrm{~s}, 25^{\circ} \mathrm{C}\right)} \rightarrow \mathrm{UO}_{3\left(\sin , 802^{\circ} \mathrm{C}\right)}$ & $\begin{array}{l}\Delta H_{3}=26.67 \pm 4.02(3) \\
\quad(\text { Guo et al., } 2015 \mathrm{~b})\end{array}$ \\
\hline (4) $\mathrm{UO}_{2\left(\mathrm{~s}, 25^{\circ} \mathrm{C}\right)}+0.5 \mathrm{O}_{2\left(\mathrm{~g}, 802{ }^{\circ} \mathrm{C}\right)} \rightarrow \mathrm{UO}_{3\left(\sin , 802{ }^{\circ} \mathrm{C}\right)}$ & $\begin{array}{l}\Delta H_{4}=-125.21 \pm 3.41(5) \\
\quad(\text { Guo et al., } 2015 \mathrm{~b})\end{array}$ \\
\hline (5) $\mathrm{CaO}_{\left(\mathrm{s}, 25^{\circ} \mathrm{C}\right)} \rightarrow \mathrm{CaO}_{\left(\operatorname{sln}, 802^{\circ} \mathrm{C}\right)}$ & $\begin{array}{c}\Delta H_{5}=-7.10 \pm 2.30(13) \\
(\text { Cheng and Navrotsky, } \\
\text { 2005) }\end{array}$ \\
\hline (6) $\mathrm{ZrO}_{2\left(\mathrm{~s}, 25^{\circ} \mathrm{C}\right)} \rightarrow \mathrm{ZrO}_{2\left(\sin , 802^{\circ} \mathrm{C}\right)}$ & $\begin{array}{c}\Delta H_{6}=82.90 \pm 0.70(8)(\text { Lee } \\
\text { et al., 2003) }\end{array}$ \\
\hline (7) $\mathrm{SiO}_{2\left(\mathrm{~s}, 25^{\circ} \mathrm{C}\right)} \rightarrow \mathrm{SiO}_{2\left(\sin , 802^{\circ} \mathrm{C}\right)}$ & $\begin{array}{l}\Delta H_{7}=49.90 \pm 0.80(9) \\
\text { (Mazeina et al., 2005) }\end{array}$ \\
\hline (8) $\mathrm{Fe}_{2} \mathrm{O}_{3\left(\mathrm{~s}, 25^{\circ} \mathrm{C}\right)} \rightarrow \mathrm{Fe}_{2} \mathrm{O}_{3\left(\sin , 802^{\circ} \mathrm{C}\right)}$ & $\begin{array}{l}\Delta H_{8}=182.29 \pm 1.34(8) \\
\quad(\text { Lilova et al., 2012) }\end{array}$ \\
\hline (9) $\left[\mathrm{Fe}_{0.947} \mathrm{O}_{\left(\mathrm{s}, 25^{\circ} \mathrm{C}\right)}+0.053 \mathrm{Fe}_{\left(\mathrm{s}, 25^{\circ} \mathrm{C}\right)}\right]+1 / 4 \mathrm{O}_{2\left(\mathrm{~g}, 25^{\circ} \mathrm{C}\right)} \rightarrow 1 / 2 \mathrm{Fe}_{2} \mathrm{O}_{3\left(\mathrm{~s}, 25^{\circ} \mathrm{C}\right)}$ & $\begin{array}{c}\Delta H_{9}=-147.3 \pm 1.0(\text { Guo et } \\
\text { al., 2014a) }\end{array}$ \\
\hline (10) $1 / 3 \mathrm{U}_{3} \mathrm{O}_{8\left(\mathrm{~s}, 25^{\circ} \mathrm{C}\right)}+1 / 6 \mathrm{O}_{2\left(\mathrm{~g}, 25^{\circ} \mathrm{C}\right)} \rightarrow \gamma-\mathrm{UO}_{3\left(\mathrm{~s}, 25^{\circ} \mathrm{C}\right)}$ & $\begin{array}{l}\Delta H_{10}=-32.2 \pm 1.1(\text { Robie } \\
\text { and Hemingway, 1995) }\end{array}$ \\
\hline (11) $\mathrm{O}_{2\left(\mathrm{~g}, 25^{\circ} \mathrm{C}\right)} \rightarrow \mathrm{O}_{2\left(\mathrm{~g}, 802^{\circ} \mathrm{C}\right)}$ & $\Delta H_{11}=25.4($ Chase, 1998$)$ \\
\hline
\end{tabular}

Thermochemical cycles

Enthalpy of formation of $\mathrm{Ca}_{3} \mathrm{Zr}_{2} \mathrm{SiFe}_{2} \mathrm{O}_{12}$ from the binary oxides $\left(\Delta H_{\mathrm{f}, \mathrm{ox}}\right)$ at $25^{\circ} \mathrm{C}$ :
(12) $3 \mathrm{CaO}_{\left(\mathrm{s}, 25^{\circ} \mathrm{C}\right)}+2 \mathrm{ZrO}_{2\left(\mathrm{~s}, 25^{\circ} \mathrm{C}\right)}+\mathrm{SiO}_{2\left(\mathrm{~s}, 25^{\circ} \mathrm{C}\right)}+\mathrm{Fe}_{2} \mathrm{O}_{3\left(\mathrm{~s}, 25^{\circ} \mathrm{C}\right)} \rightarrow \mathrm{Ca}_{3} \mathrm{Zr}_{2} \mathrm{SiFe}_{2} \mathrm{O}_{12\left(\mathrm{~s}, 25^{\circ} \mathrm{C}\right)}$ $\Delta H_{\mathrm{f}, \mathrm{ox}}=-\Delta H_{1}+3 \Delta H_{5}+2 \Delta H_{6}+\Delta H_{7}+\Delta H_{8}$

Enthalpies of formation of $\mathrm{Ca}_{3}\left(\mathrm{U}_{x} \mathrm{Zr}_{2-x}\right) \mathrm{Fe}_{3} \mathrm{O}_{12}$ from binary oxides $\left(\Delta H_{\mathrm{f}, \mathrm{ox}}\right)$ at $25^{\circ} \mathrm{C}$ :
(13) $3 \mathrm{CaO}_{\left(\mathrm{s}, 25^{\circ} \mathrm{C}\right)}+(2-x) \mathrm{ZrO}_{2\left(\mathrm{~s}, 25^{\circ} \mathrm{C}\right)}+x \gamma-\mathrm{UO}_{3\left(\mathrm{~s}, 25^{\circ} \mathrm{C}\right)}+3 / 2 \mathrm{Fe}_{2} \mathrm{O}_{3\left(\mathrm{~s}, 25^{\circ} \mathrm{C}\right)} \rightarrow \mathrm{Ca}_{3}\left(\mathrm{U}_{x} \mathrm{Zr}_{2-x}\right) \mathrm{Fe}_{3} \mathrm{O}_{12}$ $+(2 x-1) / 4 \mathrm{O}_{2\left(\mathrm{~g}, 25^{\circ} \mathrm{C}\right)}$ $\Delta H_{\mathrm{f}, \mathrm{x}}=-\Delta H_{1}+3 \Delta H_{5}+(2-x) \Delta H_{6}+x \Delta H_{3}+3 / 2 \Delta H_{8}-(2 x-1) / 4 \Delta H_{11}$ $\Delta H_{13}=\Delta H_{\mathrm{f}, \mathrm{xx}}$

Enthalpies of substituting $\mathrm{Ca}_{3} \mathrm{Zr}_{2} \mathrm{SiFe}_{2} \mathrm{O}_{12}$ with $\gamma-\mathrm{UO}_{3}$ and $\mathrm{Fe}_{2} \mathrm{O}_{3}\left(\Delta H_{\text {sub }}\right)$ at $25^{\circ} \mathrm{C}$ :

(14) $\mathrm{Ca}_{3} \mathrm{Zr}_{2} \mathrm{SiFe}_{2} \mathrm{O}_{12\left(\mathrm{~s}, 25^{\circ} \mathrm{C}\right)}+x \gamma-\mathrm{UO}_{3\left(\mathrm{~s}, 25^{\circ} \mathrm{C}\right)}+1 / 2 \mathrm{Fe}_{2} \mathrm{O}_{3\left(\mathrm{~s}, 25^{\circ} \mathrm{C}\right)} \quad \Delta H_{14}=\Delta H_{\text {sub }}$ $\rightarrow \mathrm{Ca}_{3}\left(\mathrm{U}_{x} \mathrm{Zr}_{2-x}\right) \mathrm{Fe}_{3} \mathrm{O}_{12\left(\mathrm{~s}, 25^{\circ} \mathrm{C}\right)}+x \mathrm{ZrO}_{2\left(\mathrm{~s}, 25^{\circ} \mathrm{C}\right)}+\mathrm{SiO}_{2\left(\mathrm{~s}, 25^{\circ} \mathrm{C}\right)}+(2 x-1) / 4 \mathrm{O}_{2\left(\mathrm{~g}, 25^{\circ} \mathrm{C}\right)}$

$$
\Delta H_{\text {sub }}=\Delta H_{13}-\Delta H_{12}
$$

Enthalpies of substituting $\mathrm{Ca}_{3} \mathrm{Zr}_{2} \mathrm{SiFe}_{2} \mathrm{O}_{12}$ with $\gamma-\mathrm{UO}_{3}$ and $\mathrm{FeO}\left(\Delta H_{\text {sub }}\right.$ ) at $25^{\circ} \mathrm{C}$ :

(15) $\mathrm{Ca}_{3} \mathrm{Zr}_{2} \mathrm{SiFe}_{2} \mathrm{O}_{12\left(\mathrm{~s}, 25^{\circ} \mathrm{C}\right)}+x \gamma-\mathrm{UO}_{3\left(\mathrm{~s}, 25^{\circ} \mathrm{C}\right)}+\mathrm{FeO}_{\left(\mathrm{s}, 25^{\circ} \mathrm{C}\right)}{ }^{*}+(1-x) / 2 \mathrm{O}_{2\left(\mathrm{~g}, 25^{\circ} \mathrm{C}\right)}$

$\rightarrow \mathrm{Ca}_{3}\left(\mathrm{U}_{x} \mathrm{Zr}_{2-x}\right) \mathrm{Fe}_{3} \mathrm{O}_{12\left(\mathrm{~s}, 25^{\circ} \mathrm{C}\right)}+x \mathrm{ZrO}_{2\left(\mathrm{~s}, 25^{\circ} \mathrm{C}\right)}+\mathrm{SiO}_{2\left(\mathrm{~s}, 25^{\circ} \mathrm{C}\right)}$

$$
\Delta H_{\text {sub }}=\Delta H_{14}+\Delta H_{9}
$$

Enthalpies of substituting $\mathrm{Ca}_{3} \mathrm{Zr}_{2} \mathrm{SiFe}_{2} \mathrm{O}_{12}$ with $\mathrm{U}_{3} \mathrm{O}_{8}$ and $\mathrm{Fe}_{2} \mathrm{O}_{3}\left(\Delta H_{\text {sub }}\right.$ ') at $25^{\circ} \mathrm{C}$ :
(16) $\mathrm{Ca}_{3} \mathrm{Zr}_{2} \mathrm{SiFe}_{2} \mathrm{O}_{12\left(\mathrm{~s}, 25^{\circ} \mathrm{C}\right)}+x / 3 \mathrm{U}_{3} \mathrm{O}_{8\left(\mathrm{~s}, 25^{\circ} \mathrm{C}\right)}+1 / 2 \mathrm{Fe}_{2} \mathrm{O}_{3\left(\mathrm{~s}, 25^{\circ} \mathrm{C}\right)}+(1 / 4-x / 3) \mathrm{O}_{2\left(\mathrm{~g}, 25^{\circ} \mathrm{C}\right)} \quad \Delta H_{16}=\Delta H_{\text {sub }}$ ", $\rightarrow \mathrm{Ca}_{3}\left(\mathrm{U}_{x} \mathrm{Zr}_{2-x}\right) \mathrm{Fe}_{3} \mathrm{O}_{12\left(s, 25^{\circ} \mathrm{C}\right)}+x \mathrm{ZrO}_{2\left(\mathrm{~s}, 25^{\circ} \mathrm{C}\right)}+\mathrm{SiO}_{2\left(\mathrm{~s}, 25^{\circ} \mathrm{C}\right)}$ $\Delta H_{\text {sub }}=\Delta H_{14}+x \Delta H_{10}$
$\mathrm{Fe}^{2+}$ oxide was estimated based on $\left(\mathrm{Fe}_{0.947} \mathrm{O}+0.053 \mathrm{Fe}\right)$.


Table 3. Thermodynamic data of $\mathrm{Ca}_{3}\left(\mathrm{U}_{x} \mathrm{Zr}_{2-x}\right) \mathrm{Fe}_{3} \mathrm{O}_{12}$ garnets.

\begin{tabular}{|c|c|c|c|c|c|}
\hline Sample & $\underset{(\mathrm{kJ} / \mathrm{mol})^{*}}{\Delta H_{\text {sub }}}$ & $\begin{array}{c}\Delta H_{\text {sub }}{ }^{\prime} \\
(\mathrm{kJ} / \mathrm{mol})^{\dagger}\end{array}$ & $\begin{array}{c}\Delta H^{800{ }^{\circ} \mathrm{C}}{ }_{\text {sub }}{ }^{\prime} \\
(\mathrm{kJ} / \mathrm{mol})^{\ddagger}\end{array}$ & $\begin{array}{c}\Delta S_{\text {sub }}{ }^{\prime}, \\
(\mathrm{J} / \mathrm{mol} \cdot \mathrm{K})\end{array}$ & $\begin{array}{c}\Delta G^{800{ }^{\circ} \mathrm{C}} \text { sub } \\
(\mathrm{kJ} / \mathrm{mol})\end{array}$ \\
\hline$x=0.5$ & $82.0 \pm 5.3$ & $-65.3 \pm 5.4$ & $32.0 \pm 5.3$ & -27.0 & $61.0 \pm 5.3$ \\
\hline$x=0.6$ & $69.1 \pm 5.2$ & $-76.9 \pm 5.3$ & $11.5 \pm 5.2$ & -8.1 & $20.2 \pm 5.2$ \\
\hline$x=0.7$ & $45.6 \pm 5.3$ & $-99.2 \pm 5.4$ & $-19.7 \pm 5.3$ & 8.1 & $-28.4 \pm 5.3$ \\
\hline
\end{tabular}

* Data calculated from $\Delta H_{14}$ in Table $2 .{ }^{\dagger}$ Data calculated from $\Delta H_{15}$ in Table 2. ${ }^{\ddagger}$ Data calculated from $\Delta H_{7}$ in Table S6. 
Figure

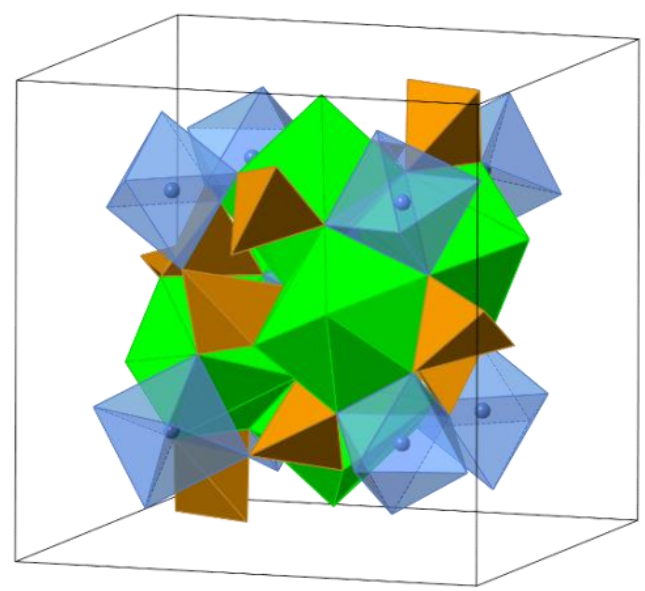

Figure 1. Crystal structure of garnet: green $-\left[\mathrm{CaO}_{20}\right]$ dodecahedra; blue $-\left[\mathrm{ZrO}_{6}\right]$ or $\left[\mathrm{UO}_{6}\right]$ octahedra; brown $-\left[\mathrm{FeO}_{4}\right]$ or $\left[\mathrm{SiO}_{4}\right]$ tetrahedra.

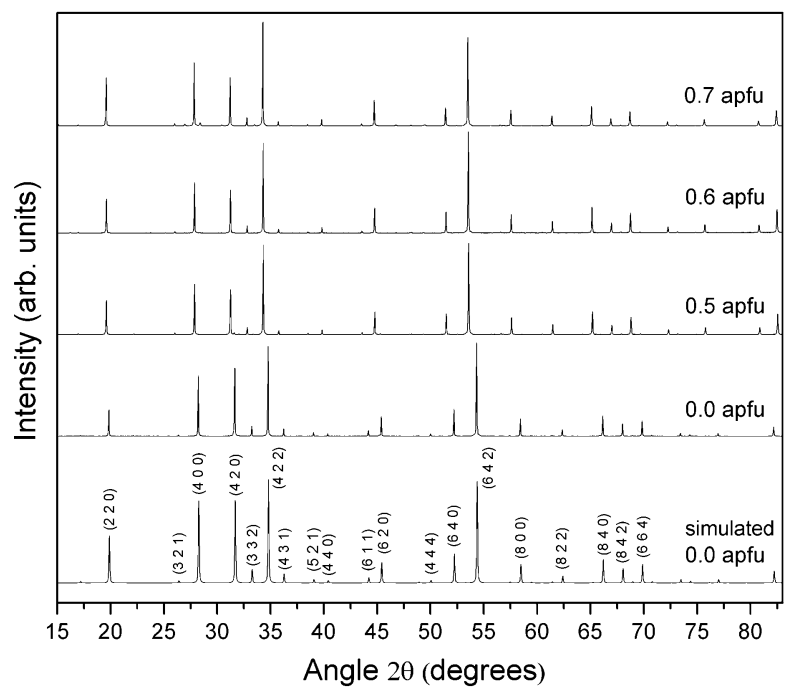

Figure 2. Powder XRD patterns of $\mathrm{Ca}_{3}\left(\mathrm{Zr}_{2}\right) \mathrm{SiFe}_{2} \mathrm{O}_{12}$ and $\mathrm{Ca}_{3}\left(\mathrm{U}_{x} \mathrm{Zr}_{2-x}\right) \mathrm{Fe}_{3} \mathrm{O}_{12}$ with $x=0.5,0.6$ and 0.7 atom per formula unit (apfu). 


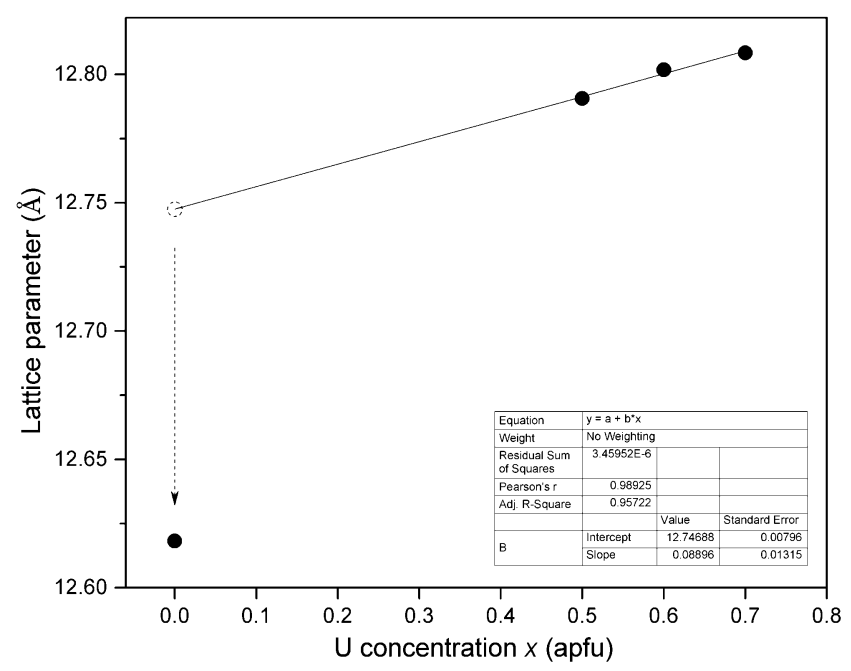

Figure 3. Lattice parameters of $\mathrm{Ca}_{3}\left(\mathrm{Zr}_{2}\right) \mathrm{SiFe}_{2} \mathrm{O}_{12}(x=0)$ and $\mathrm{Ca}_{3}\left(\mathrm{U}_{x} \mathrm{Zr}_{2-x}\right) \mathrm{Fe}_{3} \mathrm{O}_{12}(x=0.5,0.6,0.7)$ as a function of $x$. The grey circle represents the extrapolated value of linear fitting of the lattice parameters of $x=0.5,0.6$, and 0.7 to $x=0$. 

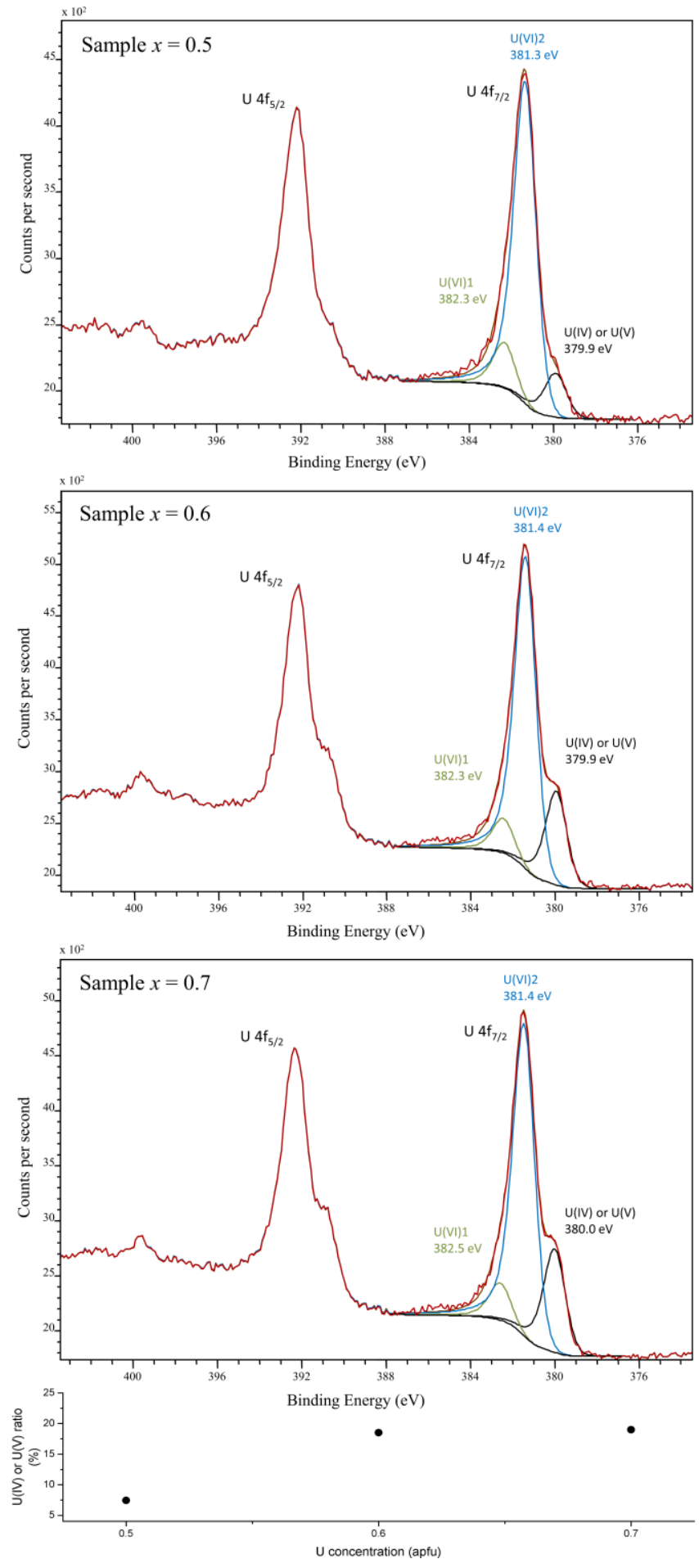

Figure 4. U4f regions of the XPS spectra of $\mathrm{Ca}_{3}\left(\mathrm{U}_{x} \mathrm{Zr}_{2-x}\right) \mathrm{Fe}_{3} \mathrm{O}_{12}$. Fittings are based on a mixture configuration of U(VI)1 (green), U(VI)2 (blue) and U(V) (black). See Table S3 in SI for details of U oxidation state configurations. Only cumulative data are plotted here. 


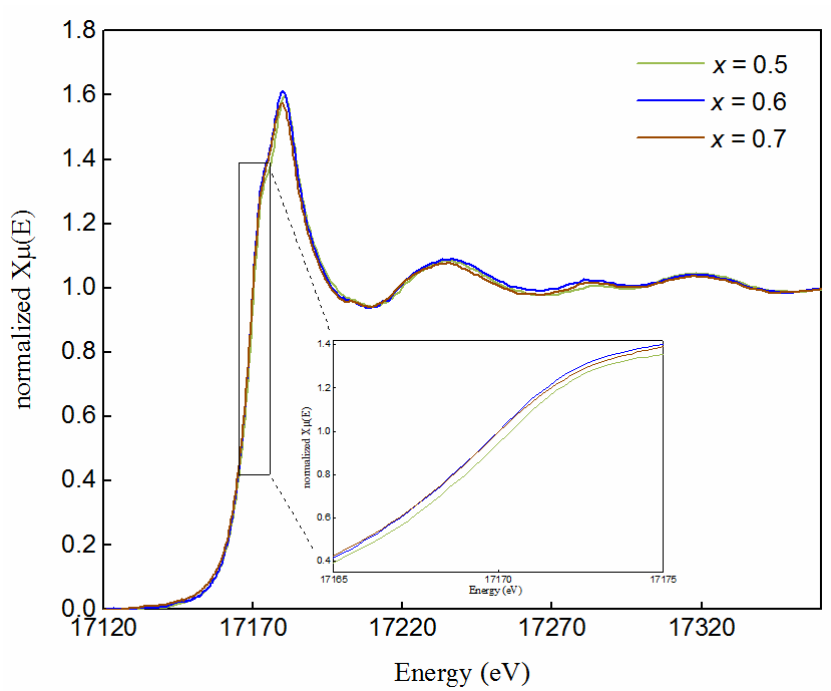

Figure 5. $\mathrm{U} \mathrm{L}_{\mathrm{III}} \mathrm{XANES}$ spectra of $\mathrm{Ca}_{3}\left(\mathrm{U}_{x} \mathrm{Zr}_{2-x}\right) \mathrm{Fe}_{3} \mathrm{O}_{12}$ garnets with $x=0.5,0.6$ and 0.7.
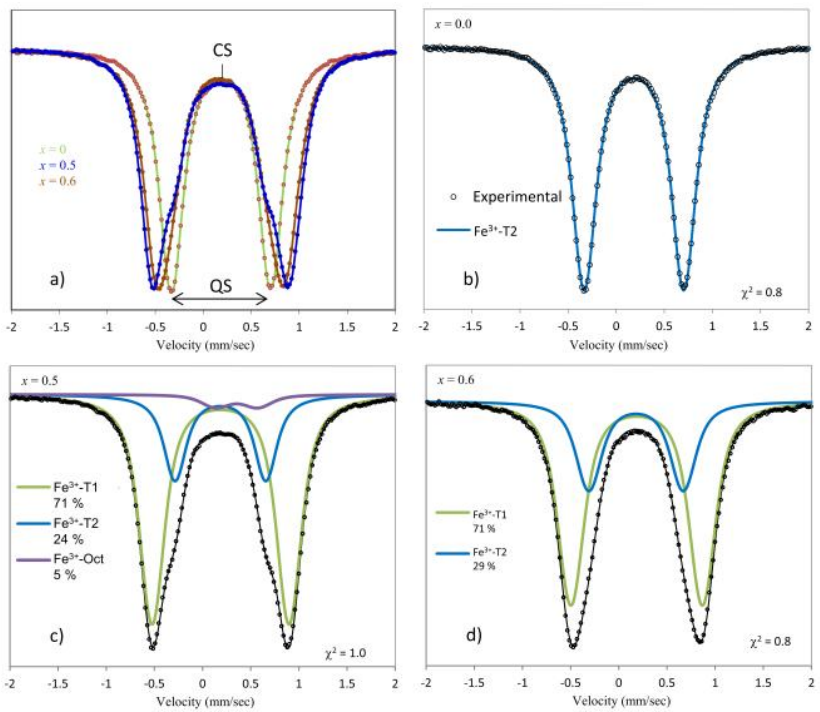

Figure 6. (a) Qualitative comparison of room temperature ${ }^{57} \mathrm{Fe}-\mathrm{Mössbauer}$ spectra of garnet samples with $x=0,0.5$ and 0.6 (spectrum of the $x=0.7$ sample is identical to that of $x=0.6$ ); (bd) Modelled spectra displaying tetrahedral doublet(s) (b) T2 in $x=0$, (c) T1 and T2 in $x=0.5$, and (d) T1 and T2 in $x=0.6$ samples. In the $x=0.5$ spectrum, the third, minor doublet $(\sim 5 \%$ of the spectral area) is due to extra-framework $\mathrm{Fe}^{3+}$ impurity [amorphous-/nano-Fe(III)-oxide(s), confirmed by $77 \mathrm{~K}$ measurement (not shown)]. 


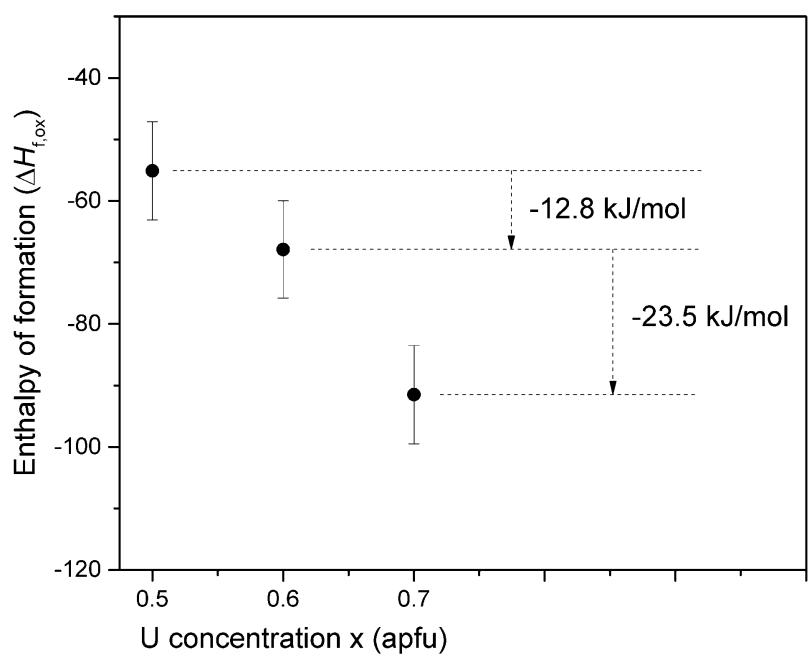

Figure 7. Enthalpies of formation of U-substituted garnets at standard conditions, based on reaction (1). 